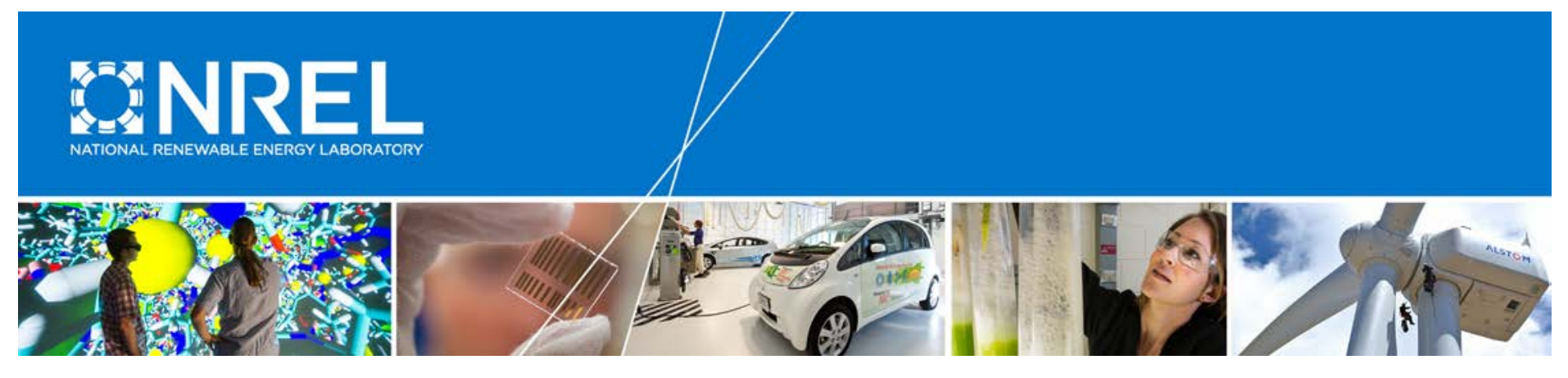

\title{
City-Level Energy Decision Making: Data Use in Energy Planning, Implementation, and Evaluation in U.S. Cities
}

Alexandra Aznar, Megan Day, Elizabeth Doris, and Shivani Mathur National Renewable Energy Laboratory

Paul Donohoo-Vallett U.S. Department of Energy

NREL is a national laboratory of the U.S. Department of Energy Office of Energy Efficiency \& Renewable Energy Operated by the Alliance for Sustainable Energy, LLC

This report is available at no cost from the National Renewable Energy Laboratory (NREL) at www.nrel.gov/publications.

Technical Report

NREL/TP-7A40-64128

July 2015 


\section{City-Level Energy Decision Making: Data Use in Energy Planning, Implementation, and Evaluation in U.S. Cities}

Alexandra Aznar, Megan Day, Elizabeth Doris, and Shivani Mathur

National Renewable Energy Laboratory

Paul Donohoo-Vallett

U.S. Department of Energy

Prepared under Task No. SA15.0801

NREL is a national laboratory of the U.S. Department of Energy Office of Energy Efficiency \& Renewable Energy Operated by the Alliance for Sustainable Energy, LLC

This report is available at no cost from the National Renewable Energy Laboratory (NREL) at www.nrel.gov/publications.

National Renewable Energy Laboratory 15013 Denver West Parkway Golden, CO 80401

303-275-3000 • www.nrel.gov

\section{Technical Report}

NREL/TP-7A40-64128

July 2015

Contract No. DE-AC36-08G028308 


\title{
NOTICE
}

This report was prepared as an account of work sponsored by an agency of the United States government. Neither the United States government nor any agency thereof, nor any of their employees, makes any warranty, express or implied, or assumes any legal liability or responsibility for the accuracy, completeness, or usefulness of any information, apparatus, product, or process disclosed, or represents that its use would not infringe privately owned rights. Reference herein to any specific commercial product, process, or service by trade name, trademark, manufacturer, or otherwise does not necessarily constitute or imply its endorsement, recommendation, or favoring by the United States government or any agency thereof. The views and opinions of authors expressed herein do not necessarily state or reflect those of the United States government or any agency thereof.

This report is available at no cost from the National Renewable Energy Laboratory (NREL) at www.nrel.gov/publications.

Available electronically at SciTech Connect http:/www.osti.gov/scitech

Available for a processing fee to U.S. Department of Energy and its contractors, in paper, from:

\author{
U.S. Department of Energy \\ Office of Scientific and Technical Information \\ P.O. Box 62 \\ Oak Ridge, TN 37831-0062 \\ OSTI http://www.osti.gov \\ Phone: 865.576.8401 \\ Fax: 865.576.5728 \\ Email: reports@osti.gov
}

Available for sale to the public, in paper, from:

\author{
U.S. Department of Commerce \\ National Technical Information Service \\ 5301 Shawnee Road \\ Alexandria, VA 22312 \\ NTIS http://www.ntis.gov \\ Phone: 800.553 .6847 or 703.605 .6000 \\ Fax: 703.605.6900 \\ Email: orders@ntis.gov
}




\section{Acknowledgments}

The authors wish to thank the following city staff for their time and contributions to this analysis: Austin Blackmon and Leah Bamberger (Boston), Kristel Riddervold (Charlottesville), Hilary Firestone (Los Angeles), Lucinda Smith and John Phelan (Fort Collins), Gayle Prest (Minneapolis), Alex Porteshawver (Benicia), Emily Randel (Mission), Carolee Williams (Charleston), Tracy Morgenstern and Sandra Mallory (Seattle), Matt Abbott (Park City), Anand Natarajan (Cleveland), Jesse Dillard (Dallas), Nicole Woodman (Flagstaff), Grant Ervin (Pittsburgh), Aaron Joseph (Chicago), Erin Gill (Knoxville), and Barbara Buffaloe (Columbia).

This analysis would not have been possible without the hard work and contributions of Megan Mercer (National Renewable Energy Laboratory [NREL]), David Zelinka (NREL), Alexander Dane (NREL), Stephen Lommele (NREL), and Ookie Ma (U.S. Department of Energy). 


\section{Foreword}

The U.S. Department of Energy's Office of Energy Efficiency and Renewable Energy has initiated a new multi-year project called Cities Leading through Energy Analysis and Planning (Cities-LEAP). Cities-LEAP aims to enable cities to lead clean energy innovation and integrate strategic energy analysis into decisions by providing standardized, localized energy data and analysis. Cities-LEAP supports the widespread implementation of city-sponsored, data-driven energy policies, programs, and projects that have the potential to drive a sea change in the national energy landscape. Through Cities-LEAP, cities will be able to:

- Set climate or energy goals

- Prioritize and implement energy strategies

- See the impacts of potential climate or energy action plans

- Learn from peers about city energy planning best practices

- Get access to credible data and transparent, usable analytic methodologies

- Make data-driven energy decisions.

The Cities-LEAP technical report, City-Level Energy Decision Making: Data Use in Energy Planning, Implementation, and Evaluation in U.S. Cities, explores how a sample of cities incorporates data into making energy-related decisions. This report provides the foundation for forthcoming components of the Cities-LEAP project that will help cities improve energy decision making by mapping specific city energy or climate policies and actions to measurable impacts and results. 


$\begin{array}{ll}\text { Acronyms } & \\ \text { CAP } & \text { climate action plan } \\ \text { CCPC } & \text { Cities for Climate Protection Campaign } \\ \text { CNG } & \text { compressed natural gas } \\ \text { GHG } & \text { greenhouse gas } \\ \text { ICLEI } & \text { International Council for Local Environmental Initiatives } \\ \text { ICMA } & \text { International City/County Management Association } \\ \text { LED } & \text { Light-Emitting Diode } \\ \text { LEED } & \text { Leadership in Energy \& Environmental Design } \\ \text { PUC } & \text { public utility commission } \\ \text { RPS } & \text { renewable portfolio standards }\end{array}$




\section{Executive Summary}

Cities in the United States are increasingly taking action to improve the sustainability of their jurisdictions. Clean energy and energy efficiency must be a central component of these efforts. This analysis uses a sample of 20 U.S. cities to explore how cities incorporate data in energy decision-making in terms of planning, implementation, and evaluation.

Many programs and tools related to city energy needs are available to decision makers (Appendix A, Figure A-1). This work identified over 30 government, foundation, non-profit, and private programs and frameworks for cities to use in energy planning. These programs provide a myriad of case studies, best practices, frameworks, and support for clean energy programs, but few align metrics with GHG reduction goals or identify clear methodologies for plan implementation and measurement of programmatic impacts.

In addition to these external resources, cities are creating sustainability, energy, and climate plans that vary in scope (e.g., city operations or community-wide), specificity, timeframe, data collection, and reporting. City staff interviewed for this research indicated that a lack of standardization in measuring impact and prioritizing actions can impede effective energy decision making.

Developing and implementing plans helps communities address their specific energy and climate priorities. The heterogeneity of plans creates a barrier, however, to understanding the plans' impacts on climate and energy goals and the broader impacts of the plans and actions on national energy use. To address this, a nomenclature system (Figure ES-1) was designed to compare climate, sustainability, and energy plans across cities.

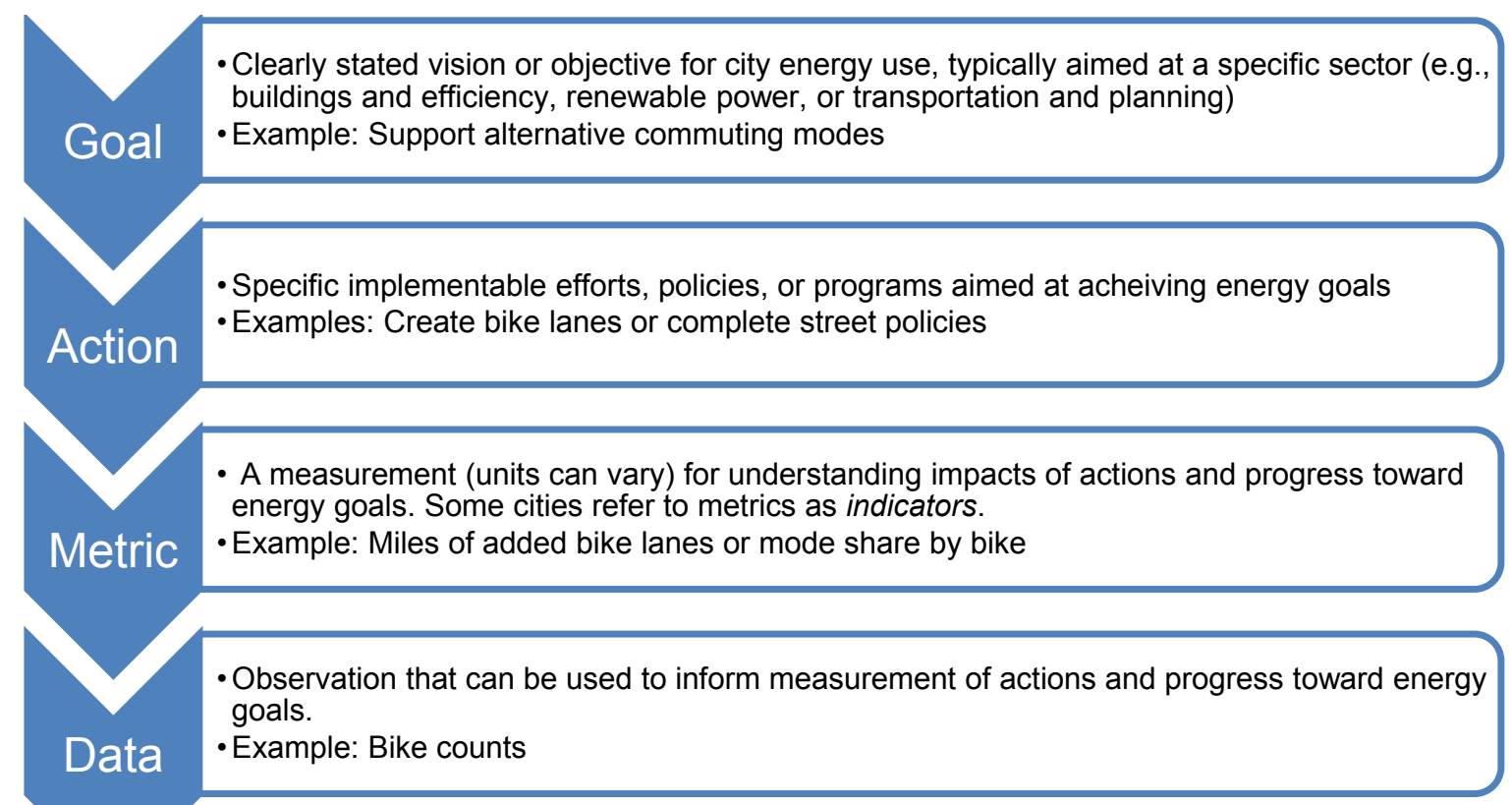

Figure ES-1. City energy decision-making framework 
Data collection from city plans and interviews with representatives of 20 cities provided a survey of city goals, the actions employed to meet those goals, and measurement strategies to track progress.

Common city energy-related goals focus on reducing carbon emissions overall (and specifically from transportation), improving energy efficiency across sectors, increasing renewable energy, and increasing biking and walking.

Categorizing the plans according to Figure ES-1 and comparing the energy-related actions indicates that cities, regardless of size, focus on energy-related actions in the following categories:

- Buildings and Efficiency

- Transportation and Land Use

- Renewable Power.

Cities sampled are planning a variety of energy-related actions, policies, and programs within these categories, the most common of which are shown in Table ES-1.

Table ES-1. Common City Energy-Related Actions

\begin{tabular}{|c|c|c|}
\hline Category & Subcategory & Action \\
\hline $\begin{array}{l}\text { Buildings and } \\
\text { Efficiency }\end{array}$ & $\begin{array}{l}\text { Building codes, standards, and } \\
\text { certifications }\end{array}$ & Building certifications and best practices \\
\hline \multirow{4}{*}{$\begin{array}{l}\text { Transportation } \\
\text { and Land Use }\end{array}$} & Land Use Planning & $\begin{array}{l}\text { Walkable, complete, mixed-use community } \\
\text { planning }\end{array}$ \\
\hline & $\begin{array}{l}\text { Improved transportation } \\
\text { options and infrastructure }\end{array}$ & Public transit service expansion \\
\hline & $\begin{array}{l}\text { Municipal fleet (passenger and } \\
\text { freight) }\end{array}$ & Municipal operational changes \\
\hline & $\begin{array}{l}\text { Improved transportation } \\
\text { options and infrastructure }\end{array}$ & Bicycle and pedestrian infrastructure \\
\hline \multirow{2}{*}{$\begin{array}{l}\text { Renewable } \\
\text { Power }\end{array}$} & Local power generation & $\begin{array}{l}\text { Distributed generation outreach and } \\
\text { communication }\end{array}$ \\
\hline & Supporting Policies & Goal and challenge issuing \\
\hline
\end{tabular}

Historically, programmatic impact measurement has proven challenging for cities; however, measurement of progress toward goals is becoming increasingly sophisticated, particularly in larger cities with greater resources. Of the 20 cities profiled in this analysis, two have no public record of evaluating energy programs or goals. Many have recently begun reporting metrics annually in reports or online dashboards, while others report less regularly (i.e. every few years). Typical metrics used by cities are summarized in Table ES-2. A comprehensive list of metrics can be found in the Appendix B, Table B-3. 
Table ES-2. Common City Energy-Related Metrics

\begin{tabular}{ll}
\hline \multicolumn{1}{c}{ Category } & \multicolumn{1}{c}{ Metric } \\
\hline Emissions & $\begin{array}{l}\text { Greenhouse gas (GHG) emissions (community-wide) (MT of } \\
\text { CO2e/year) }\end{array}$ \\
\hline Energy & Energy consumed (community-wide) (MMBtu/year) \\
\hline Renewable Power & Renewable energy production (MW installed/year) \\
\hline \multirow{3}{*}{ Buildings and Efficiency } & Energy consumption (buildings) (MMBtu/year) \\
\cline { 2 - 2 } & $\begin{array}{l}\text { Green Buildings (e.g. Leadership in Energy \& Environmental } \\
\text { Design) (number of certified buildings) }\end{array}$ \\
\hline
\end{tabular}

Common practices for planning, implementing, and measuring energy decisions include conducting regular GHG inventories; creating sustainability or climate action plans; creating, tracking, and reevaluating metrics over time to demonstrate progress; and creating updates to sustainability and climate action plans.

This analysis demonstrates that many cities with energy and climate-related goals have difficulty quantifying progress toward those goals and identifying policies that support those goals. The inability of cities to quantify the impacts of their specific actions also affirms the need for more research in this field both to support cities in action prioritization and to understand the national impacts of city energy-related actions en masse. Cities also need additional support to make energy decisions. This work illustrates that cities would benefit most from:

- Adoption of standardized methodologies for measuring GHG emissions and mapping energy goals and actions.

- A better understanding of the energy, GHG, and cost impacts of energy-related actions, or suites of actions, to help prioritize actions to achieve energy goals. 


\section{Table of Contents}

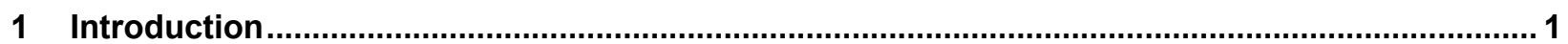

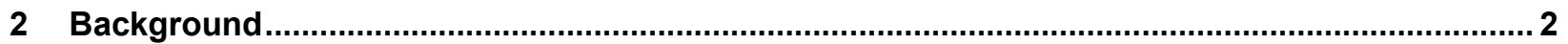

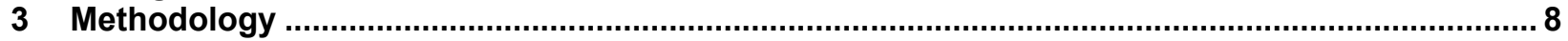

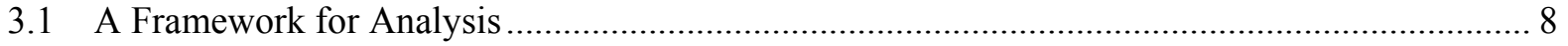

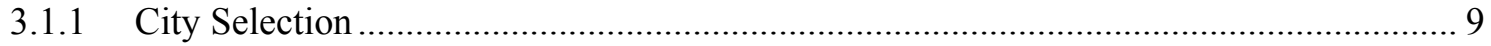

3.1.2 Climate Action and Sustainability Plans, Sustainability Websites, and Dashboards..... 11

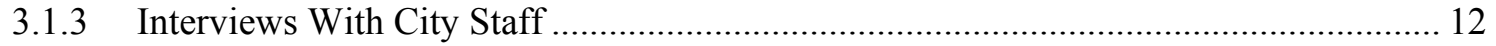

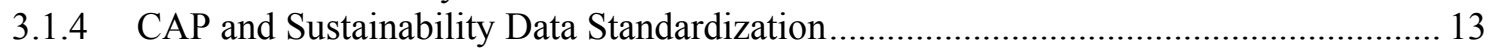

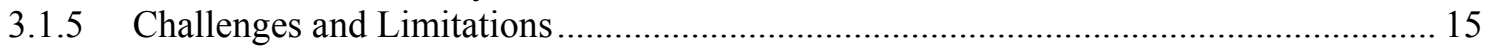

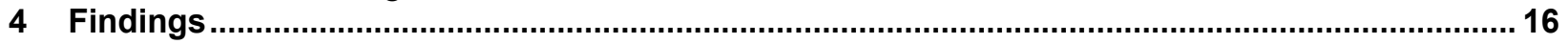

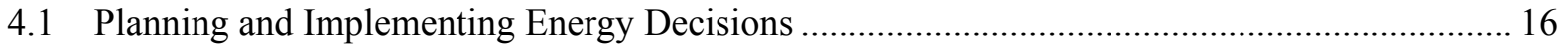

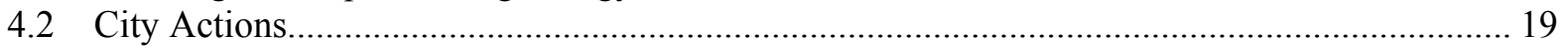

4.3 City Actions and Greenhouse Gas Emissions Abatement..................................................... 24

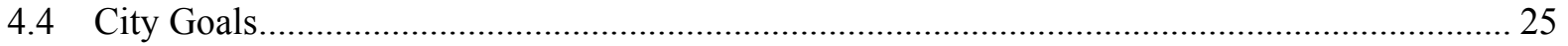

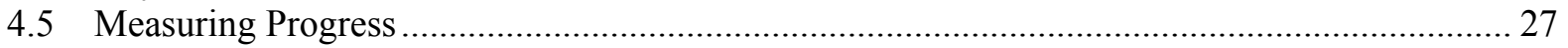

4.6 Relationship between City Goals, Actions, and Metrics: Why the Gaps? ............................... 31

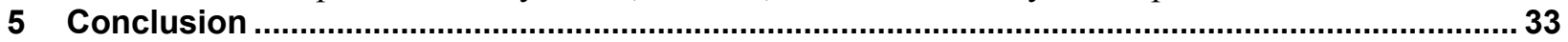

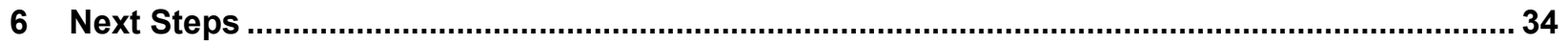

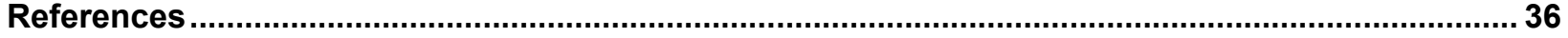

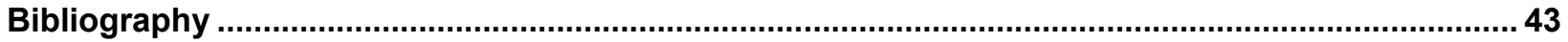

Appendix A

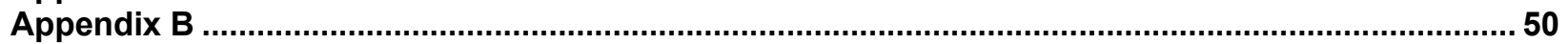




\section{List of Figures}

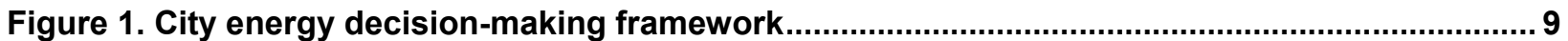

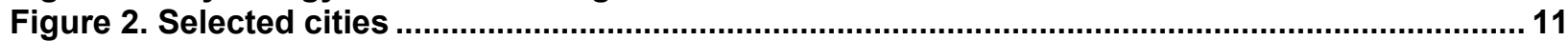

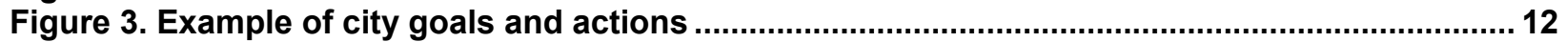

Figure 4. Summary of standardized actions by category ................................................................ 20

Figure 5. Top 10 city standardized actions (as a percent of total actions) .................................... 21

Figure 6. Top standardized action by category (percentage of total actions shown and percentage

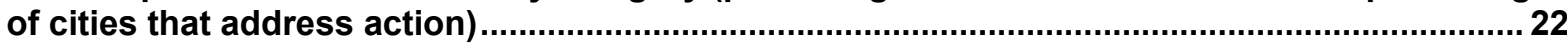

Figure 7. Summary of standardized goals by category .............................................................. 26

Figure 8. Top standardized goal within each category (percentage of total goals shown and percentage of cities that address goal) (excluding "other" category).......................................26

Figure 9. Summary of standardized metrics by category ............................................................ 27

Figure 10. Top standardized metric within each category (percentage of total metrics shown and percentage of cities that address metric) (excluding "other" category) ...................................... 28

Figure 11. One of many graphs displayed on Boston's interactive "Greenovate Boston" performance dashboard

Figure 12. Baltimore tracks the implementation stage of different actions by goal and category in its sustainability plan annual reports.

\section{List of Tables}

Table 1. Energy Actions (within the city government) ..................................................................... 4

Table 2. Energy Actions (within the community)....................................................................... 5

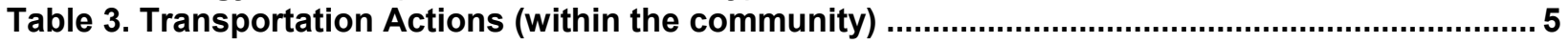

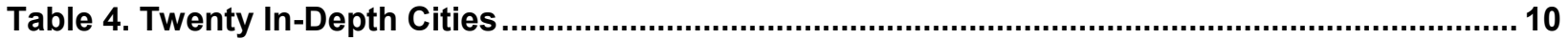

Table 5. Standardized Energy-Related Goal Categories and Subcategories ................................13

Table 6. Standardized Energy-Related Action Categories and Subcategories ................................. 14

Table 7. Standardized Energy-Related Metric Categories and Subcategories.................................15

Table 8. Common Practices From In-Depth Cities: Planning, Implementing, and Measuring Energy Decisions

Table 9. Largest Sector Contributor to GHG Emissions in Sampled Cities....................................... 18

Table 10. City Actions and GHG Abatement Estimates ............................................................ 25 


\section{Introduction}

Cities consume approximately $70 \%$ of global energy and are projected to house approximately $60 \%$ of the global population by 2030 (Seto and Dhakal 2014). Given increasing urbanization worldwide and their large energy footprint, cities are well positioned to have significant impacts on energy use. A transition to cleaner forms of energy may result in energy reliability, price stability, and cleaner air and water; it should also help city dwellers mitigate and adapt to climate change. There is increasing evidence that city decision makers are acknowledging and addressing the opportunity to achieve cost saving and resiliency benefits and to realize climate impact mitigation through clean energy innovation and actions.

In the United States, cities began formally addressing climate issues in the mid-1990s by creating greenhouse gas (GHG) emission reduction goals and climate action plans (CAPs). At this time, assistance from the U.S. Environmental Protection Agency and the International Council for Local Environmental Initiatives' (ICLEI) Cities for Climate Protection Campaign (CCPC) largely supported CAPs. The 2005 U.S. Conference of Mayors' Climate Protection Agreement was another important catalyst for the creation of city-level CAPs (Wheeler 2008). By 2007, more than 500 city mayors had signed this agreement, pledging GHG reductions in line with Kyoto Protocol targets ${ }^{1}$ (U.S. Conference of Mayors 2008). Over time, cities have continued to address energy issues in CAPs and in sustainability, energy, and environmental plans.

CAPs, energy plans, sustainability plans, and environmental plans provide a survey of how U.S. cities grapple with energy issues, but they do not tell the entire story of how cities make energy decisions. Understanding city decision making, actions, and metrics in the energy and climate domain enables organizations to better provide the resources and tools cities need to lead clean energy and low-carbon innovation. Categorizing these actions and metrics provides insight into pathways for national impact of collective city actions. An extensive body of literature synthesizes city needs and experiences concerning myriad energy topics. This report augments that literature by surveying and summarizing how city governments approach energy decision making, how cities measure progress toward those goals, and what challenges city policymakers encounter in this effort.

This report begins with a discussion of academic literature related to - and organizations involved in - city sustainability planning and implementation. A discussion of the methodology employed in this analysis follows. Three categories of analysis findings are discussed: planning and implementing energy decisions; city actions, city goals, and city metrics; and why city actions and goals might not match on-the-ground efforts. The analysis concludes with suggestions for a path forward.

1 “7\% reduction from 1990 levels by 2012” (U.S. Conference of Mayors 2008). 


\section{Background}

Many cities are currently engaged in a range of activities under umbrella labels such as "sustainability," "environment," and "resiliency." A vast array of academic and gray literature has reported on these local initiatives. An understanding of city roles in climate change governance, along with an increasing emphasis on evaluating the gaps between city actions and plans, have dominated past research on cities and climate change. Gaps remain in understanding how cities use data for energy decision making.

City energy decision making is often bounded by jurisdictional control or the level of authority a city has. Several areas that impact community-wide energy use-transportation, land-use planning, and building codes, for example-fall under the purvey of local governments, including cities (Coenen and Menkveld 2002). However, jurisdictional control is complex in practice due to the recognition of only federal, state, and American Indian tribal nation powers in the U.S. Constitution. Some "home rule" states permit local governments significant decision making authority, while "Dillon's rule" states grant more limited authority (Stout 2014). Overlapping jurisdictional control is common.

There is evidence that local governments in states with clean energy policies, such as renewable portfolio standards (RPS), are more likely to have also adopted clean energy policies (Busche 2010; Peterson et al. 2011) — this is one indication of how state policy influences local jurisdictions. Local governments, such as cities, can experiment with energy-related policies in ways a state cannot and may better understand how to frame energy issues to their constituents. On the other hand, local energy decision making can potentially create inconsistent requirements for industry and be duplicative, wasting time and resources (Busche 2010). Busche (2010) found that "complementary policy development at the multiple levels of government is critical to developing a consistent market for clean energy."

Creating CAPs has been a key process by which cities organize their goals and actions to meet those goals. ICLEI's CCPC and ClearPath are examples of tools that have supported CAPs in the United States. CCPC has been extensively reviewed in academic literature to understand the importance of "global environmental politics" and "multilevel governance" in sustainability (Bulkeley and Betsill 2005; Lindseth 2004.; Betsill and Bulkeley 2006; Anguelovski and Carmin 2011; Corfee-Morlot et al. 2009; Zahran, Grover et al. 2008; Krause 2010; Svara et al. 2013). Researchers have sought to understand cities' motivations to adopt climate-related initiatives (Zahran et al. 2008; Krause 2010; Svara et al. 2013). Their work indicates that cities that are high emitters of GHGs are less likely to engage in climate protection activities, while cities with higher civic capacities - measured by income, education, and age - are more likely to participate in such activities (Zahran et al. 2008; Portney 2002). Kousky and Schneider (2003) find cobenefits and cost savings of reducing GHG emissions to be the main drivers motivating municipalities to engage in climate protection initiatives. Examining the role of civic engagement in sustainable development, Portney concludes that American cities that are more participatory are likely to engage in sustainability activities (Portney 2005; Portney and Berry 2010).

Betsill (2001) built on experience gained by cities through the CCPC to determine that there are institutional barriers in converting climate policy into action in cities. Based on the current 
understanding of local sustainability programs, Stone et al. (2012) concluded that current CAPs and programs in states and cities do not adequately address rising GHG emissions and their associated effects. Millard-Ball (2012) reached a similar conclusion in his empirical analysis of whether a causal relationship exists between a city adopting a CAP and reduced GHG emissions. According to Millard-Ball, adopting a CAP has no causal impact on GHG emissions, but rather codifies "outcomes that would have been achieved in any case" because of strong constituent support for environment and climate initiatives (Millard-Ball 2012, p. 289). These studies, however, draw conclusions from small samples of city plans.

Local climate protection literature has also sought to develop an understanding of current CAP processes and methods, associated gaps, and measures to address these gaps. Case study literature analyzes innovative sustainability initiatives of local governments ranging from energy efficiency to climate adaptation to recycling (Svara et al. 2011; U.S. Conference of Mayors 2006). Erikson et al. (2013) studied the types of GHG reduction programs and technologies (and their GHG abatement potential) local governments can implement across various sectors (e.g., energy, transport, and waste).

Energy efficiency is an especially well-covered topic in city literature. Some research uses computational models to addresses how city energy systems can become more efficient through planning and design (Keirstead and Shah 2013); others analyze funding mechanisms local governments have employed for various energy efficiency initiatives (Mackres and Hayes 2012). The American Council for an Energy-Efficient Economy annually consolidates local best practices in energy efficiency via its city energy efficiency scorecard. Like its predecessors (ACEE 2006-2012), the 2013 American Council for an Energy-Efficient Economy City Energy Efficiency Scorecard provides a benchmark by ranking a sample of 32 cities on their adoption of actions that advance energy efficiency across five policy areas: local government operations, community-wide initiatives, building policies, energy and water utilities, and transportation policies (ACEEE 2013). The scorecard's best practices and ranking system guide cities seeking to achieve their energy and climate goals through energy efficiency measures and demonstrate the uptake of these best practices by sampled cities.

While the CAPs are a good indication of cities' planned actions and goals, they do not fully capture what actions cities actually implement. Some organizations have explored city energy agendas in detail. For example, in 2010 the International City/County Management Association (ICMA) issued a survey to 8,569 local U.S. governments and collected data from 2,176 respondents to understand sustainability and energy-related actions cities have implemented. The survey found the most common energy-related municipal operations action cities take is conducting energy audits of government buildings, the most commonly implemented community-wide action is weatherization programs for individual residences, and the most commonly implemented transportation action in the community is adding biking and walking trails (ICMA 2010) (see Table 1 through Table 3). 
Table 1. Energy Actions (within the city government)

Which of the following actions has your government taken to decrease its use of energy?

\begin{tabular}{ll}
\multicolumn{1}{c}{ Action } & $\begin{array}{c}\text { Local Government Has } \\
\text { Taken Action } \\
\text { (\% reporting) }\end{array}$ \\
\hline Conducted energy audits of government buildings & 62.9 \\
\hline Upgraded or retrofitted facilities to higher energy efficiency office lighting & 55.9 \\
\hline $\begin{array}{l}\text { Installed energy management systems to control heating and cooling in } \\
\text { buildings }\end{array}$ & 46.4 \\
\hline Increased the purchase of fuel efficient vehicles & 44.4 \\
\hline $\begin{array}{l}\text { Upgraded or retrofitted facilities to higher energy efficiency heating and air } \\
\text { conditioning systems }\end{array}$ & 39.3 \\
\hline Upgraded or retrofitted traffic signals to improve efficiency & 37.1 \\
\hline $\begin{array}{l}\text { Upgraded or retrofitted streetlights and/or and other exterior lighting to } \\
\text { improve efficiency }\end{array}$ & 30.5 \\
\hline Purchased hybrid electric vehicles & 23.7 \\
\hline $\begin{array}{l}\text { Upgraded or retrofitted facilities to higher energy efficiency pumps in the } \\
\text { water or sewer systems }\end{array}$ & 23.4 \\
\hline $\begin{array}{l}\text { Established policy to only purchase ENERGY STAR equipment when } \\
\text { available }\end{array}$ & 17.4 \\
\hline Utilized dark sky compliant outdoor light fixtures & 15.1 \\
\hline Installed solar panels on a government facility & 13.1 \\
\hline Established a fuel efficiency target for the government fleet of vehicles & 12.5 \\
\hline Purchased vehicles that operate on compressed natural gas (CNG) & 8.5 \\
\hline $\begin{array}{l}\text { Generated electricity through municipal operations such as refuse disposal, } \\
\text { wastewater treatment, or landfill }\end{array}$ & 7.4 \\
\hline Installed a geo-thermal system & 6.6 \\
\hline Installed charging stations for electric vehicles & 5.3 \\
\hline
\end{tabular}


Table 2. Energy Actions (within the community)

Please indicate which of the following actions your local government has taken to reduce energy consumption in the community.

\begin{tabular}{lccc}
\hline \multicolumn{1}{c}{ Action } & $\begin{array}{c}\text { Direct Grant } \\
\text { (\% Reporting) }\end{array}$ & $\begin{array}{c}\text { Direct Loan } \\
\text { (\% Reporting) }\end{array}$ & $\begin{array}{c}\text { Tax Incentive } \\
\text { (\% Reporting) }\end{array}$ \\
\hline Weatherization-Individual Residences & 11.1 & 2.9 & 0.6 \\
\hline Energy Audit-Individual Residences & 6.4 & 0.9 & 0.3 \\
\hline $\begin{array}{l}\text { Heating/Air Conditioning Upgrades- } \\
\text { Individual Residences }\end{array}$ & 5.5 & 2.3 & 0.6 \\
\hline $\begin{array}{l}\text { Purchase of Energy-Efficient } \\
\text { Appliances-Individual Residences }\end{array}$ & 4.7 & 0.8 & 0.1 \\
\hline Energy Audit-Businesses & 4.2 & 0.5 & 0.3 \\
\hline $\begin{array}{l}\text { Heating/Air Conditioning Upgrades- } \\
\text { Businesses }\end{array}$ & 3.4 & 1.1 & 0.3 \\
\hline $\begin{array}{l}\text { Weatherization-Businesses } \\
\text { Purchase of Energy Efficient }\end{array}$ & 2.8 & 1.1 & 0.3 \\
\hline $\begin{array}{l}\text { Appliances-Businesses } \\
\text { Installation of Solar Equipment- } \\
\text { Individual Residences }\end{array}$ & 2.7 & 0.7 & 1.3 \\
\hline $\begin{array}{l}\text { Installation of Solar Equipment- } \\
\text { Businesses }\end{array}$ & 1.4 & 1 & 0.8 \\
\hline
\end{tabular}

Table 3. Transportation Actions (within the community)

Within the last 5 years, which of the following transportation improvements has your community implemented?

\begin{tabular}{lc}
\multicolumn{1}{c}{ Action } & $\begin{array}{c}\text { Local Government Has Initiated } \\
\text { (\% reporting) }\end{array}$ \\
\hline Added biking and walking trails & 61.4 \\
\hline Required sidewalks in new developments & 54.4 \\
\hline Expanded dedicated bike lanes on streets & 34.2 \\
\hline Added bike parking facilities & 27.8 \\
\hline Widened sidewalks & 24.5 \\
\hline Expanded bus routes & 21.9 \\
\hline Required bike storage facilities & 8 \\
\hline Required showers and changing facilities for employees & 4 \\
\hline Required charging stations for electric vehicles & 1.2 \\
\hline
\end{tabular}

Other researchers have incorporated and built upon the ICMA (2010) survey results. Svara et al. (2013) discuss the ICMA survey results and create statistical models to explain what motivates cities to adopt different sustainability practices. They conclude that cities that have made commitments to "larger issues addressed by the sustainability movement appear more likely to 
take sustainability-related actions compared to their counterparts who do not prioritize sustainability," and that "the later adopters and the laggards represent a supermajority that is holding down the extent of commitment for the local government sector as a whole. Perhaps the most blatant indicator of limited commitment is the absence of goals and targets for most government sustainability programs" (Svara et al. 2013, p. 34)."

A number of third-party tools are available to aid typically resource-constrained cities in both collecting and understanding data related to energy use and GHG emissions. The U.S. Department of Energy, the U.S. Environmental Protection Agency, and ICLEI have been forerunners in providing cities with tools and resources for implementing local sustainability initiatives. An increasing number of organizations in the private, public, and nonprofit sectors devoted to sustainability issues in the built environment, the natural environment, and the intersection of the two have developed tools and resources to help cities collect and analyze data and estimate the impacts of energy-related actions. These tools are summarized in Appendix A, Figure A-1.

Comprehensive guides about energy are available for cities interested in creating strategic energy plans (DOE 2013), as are evaluations of local energy planning efforts (Mackres and Kazerooni (2012). The EPA's “Local Government Climate and Energy Strategy Series" discusses a variety of GHG emission reduction strategies within the energy efficiency, transportation, urban planning and design, waste management, and renewable energy sectors that local governments can adopt (EPA 2011-2014). A growing body of system-level analyses makes the connections between urban growth patterns, energy use, climate change, and economics (Global Commission on the Economy and Climate 2014). The U.S. Community Protocol for Accounting and Reporting of Greenhouse Gas Emissions (ICLEI 2012) was developed as a guide for local governments to report community GHG emissions. Local Government Operations Protocol ${ }^{2}$ supports city governments in reporting emissions associated with government operations (CARB 2010). These protocols provides the analytical foundation for ICLEI's Clear Path ${ }^{3}$ software (OpenEI 2015) — a data-intensive tool many cities use to calculate municipal and communitywide GHG emissions inventories.

Cities that want to understand how they can plan, measure, and evaluate a suite of sustainability goals and activities can consult the Sustainability Tool for Assessing and Rating Communities for a useful framework as part of their certification programs (STAR Communities 2014). While the CACP and Sustainable Tool for Assessing and Rating Communities are becoming commonly used resources for furthering cities' understanding of sustainability progress, interest from cities in how to measure their energy use and understand the impact of programs, all while in the pursuit of energy goals, persists. For example, peer exchange groups such as the Urban Sustainability Directors Network are creating working groups on topics such as accessing utility data and developing sustainability indicators (Bauer 2014).

\footnotetext{
2 This protocol was developed by ICLEI Local Governments for Sustainability, the California Air Resource Board, the California Climate Action Registry, the Climate Registry, and other stakeholders as part of the California Air Resources Board's implantation of California's AB32 legislation aimed at cutting California GHG emissions (CARB 2010).

${ }^{3}$ Formerly known as CACP.
} 
While scholars lay the framework for understanding the ways cities behave toward climate change and sustainability, gaps remain in the literature in the area of understanding broadly how cities are making energy-related decisions and measuring progress toward clean energy goals. Little research has been done to directly analyze local CAPs in depth (Wheeler 2008; Tang et al. 2010; Bassett and Shandas 2010). Tang et al. (2010) study CAPs to analyze their recognition of climate change concepts. Bassett and Shandas (2010) analyze processes and products of CAPs and their implementation and attempt to understand actions adopted by cities in CAPs; Wheeler (2008) assesses goals, measures, and implementation processes of CAPs.

This research, building on the work done by Wheeler (2008) and Bassett and Shandas (2010), addresses a remaining gap in the literature by analyzing the goals, actions, and metrics used by 20 cities in their energy-related plans. The intent is to inform the understanding of the relationship of goals, actions, and metrics laid out in CAPs by cities, along with how this influences their implementation. 


\section{Methodology}

This section first seeks to define the terms energy-related and city.

City actions can impact energy use either directly or indirectly. For example, building energy codes can directly impact the energy consumed by buildings, while adding sidewalks may promote more walking and less driving, thus indirectly impacting fuel use. In this report, energyrelated is defined as:

- Impacting the use of electricity, oil, and natural gas (for buildings, transportation, or other purposes)

- Impacting the production of energy within city boundaries.

This analysis also evaluates GHG emissions from these energy-related sources. Other city departments and directives target areas related to energy, such as water use and waste, but lie outside the scope of this analysis.

Throughout this paper, the term city refers to an incorporated place as defined by the U.S. Census. ${ }^{4}$ More generally, a city can be thought of as an urbanized area with a distinct form of government. This analysis captures trends from a diverse, nonscientific sample of 20 of the nearly 20,000 municipalities in the United States (U.S. Census Bureau 2015).

\subsection{A Framework for Analysis}

This study analyzed city energy decision making by applying a framework composed of four concepts: goals, actions, metrics, and data (Figure 1).

\footnotetext{
${ }^{4}$ Defined as "cities, towns (except in New England, New York, and Wisconsin where the Census Bureau recognizes towns as MCDs for census purposes), boroughs (except in Alaska, where the Census Bureau recognizes boroughs as equivalents of counties, and New York, where the Census Bureau recognizes the five boroughs that constitute New York City as MCDs), villages, and other lesser known identifiers” (U.S. Census 2015).
} 


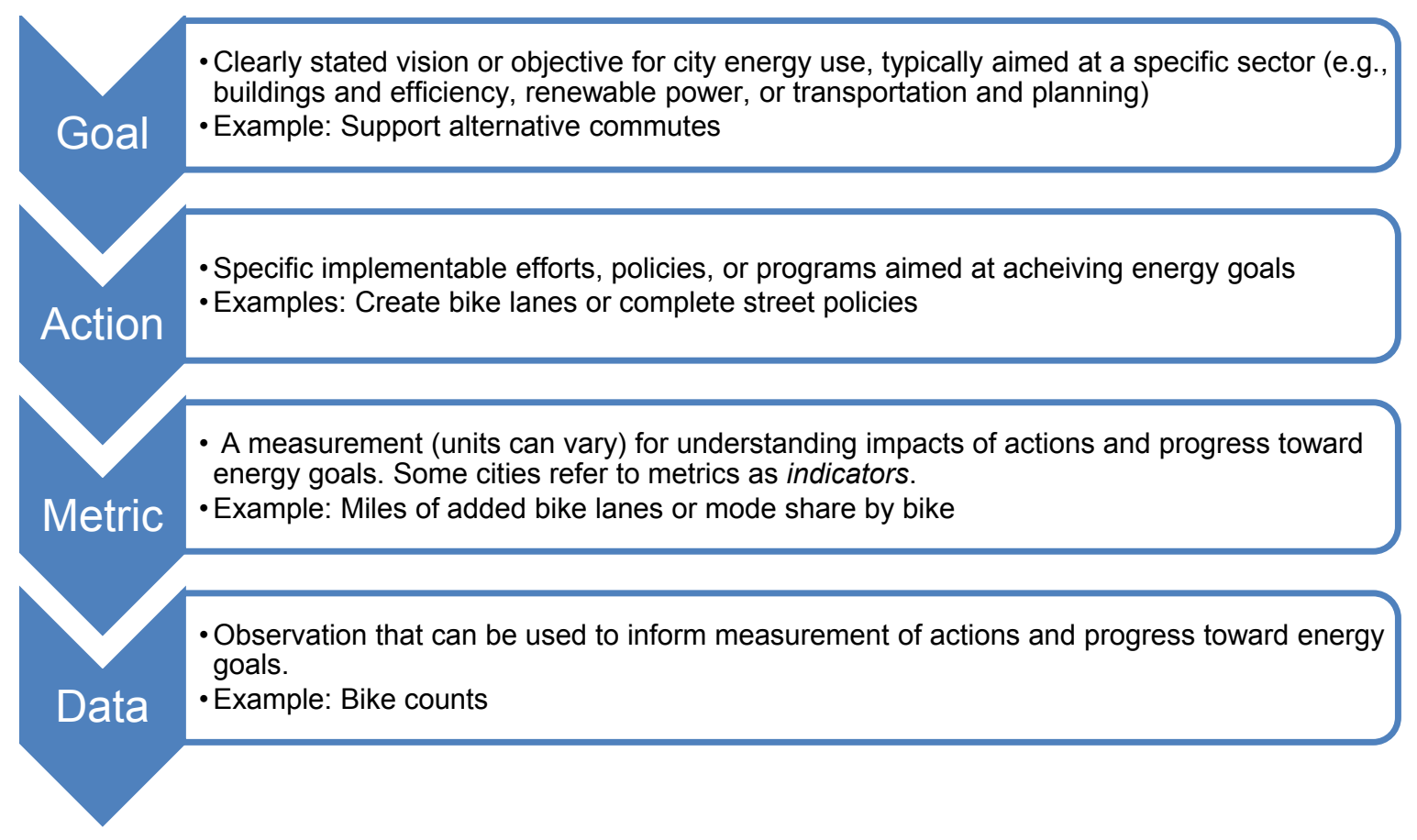

Figure 1. City energy decision-making framework

\subsubsection{City Selection}

To understand cities' energy-related actions, goals, and metrics, which cities actually implement actions, and how they track progress over time, 20 cities were selected for an in-depth analysis. The sample cities were selected from a list of cities that met the following baseline criteria:

- They must be characterized as incorporated places.

- They have a published GHG reduction goal; because the goal of the report is to understand how cities develop and make progress toward climate or energy goals, the sample set is designed to preselect cities with those goals.

These selection criteria yielded a sample of 139 cities. From these, 20 cities (Table 4 and Figure 2) were selected for in-depth profiles and analysis to represent a diverse sample of the following factors that impact urban energy use (Bai et al. 2013):

- Population size and density. Size classified as small (1,000-49,999 inhabitants), medium (50,000-499,999 inhabitants), and large (over 500,000 inhabitants). Density classified as low ( $<750$ persons/square mile), medium (750-7,000 persons/square mile), and high $(>7,000$ persons/square mile).

- Utility type. Investor-owned utility, municipal utility, and cooperative.

- Region. Cities were selected from each of the four U.S. Census-designated regions: Northeast, South, Midwest, and West.

- Percent annual GHG reduction target. Low, moderate, and aggressive annual reduction targets. 
- Value of all goods traded (annually) between a city and its trading partners. A proxy for economic diversity and power.

- Daily vehicle miles traveled. Associated with city density and alternative transportation infrastructure.

- Median household income. A socioeconomic indicator.

Table 4. Twenty In-Depth Cities

\begin{tabular}{|c|c|}
\hline City & State \\
\hline Baltimore & Maryland \\
\hline Benicia & California \\
\hline Boston & Massachusetts \\
\hline Charleston & South Carolina \\
\hline Charlottesville & Virginia \\
\hline Chicago & Illinois \\
\hline Cleveland & Ohio \\
\hline Columbia & Missouri \\
\hline Dallas & Texas \\
\hline Flagstaff & Arizona \\
\hline Fort Collins & Colorado \\
\hline Hartford & Connecticut \\
\hline Knoxville & Tennessee \\
\hline Los Angeles & California \\
\hline Minneapolis & Minnesota \\
\hline Mission & Kansas \\
\hline New York & New York \\
\hline Park City & Utah \\
\hline Pittsburgh & Pennsylvania \\
\hline Seattle & Washington \\
\hline
\end{tabular}

Emphasis was placed on population size and density as a selection criteria. 


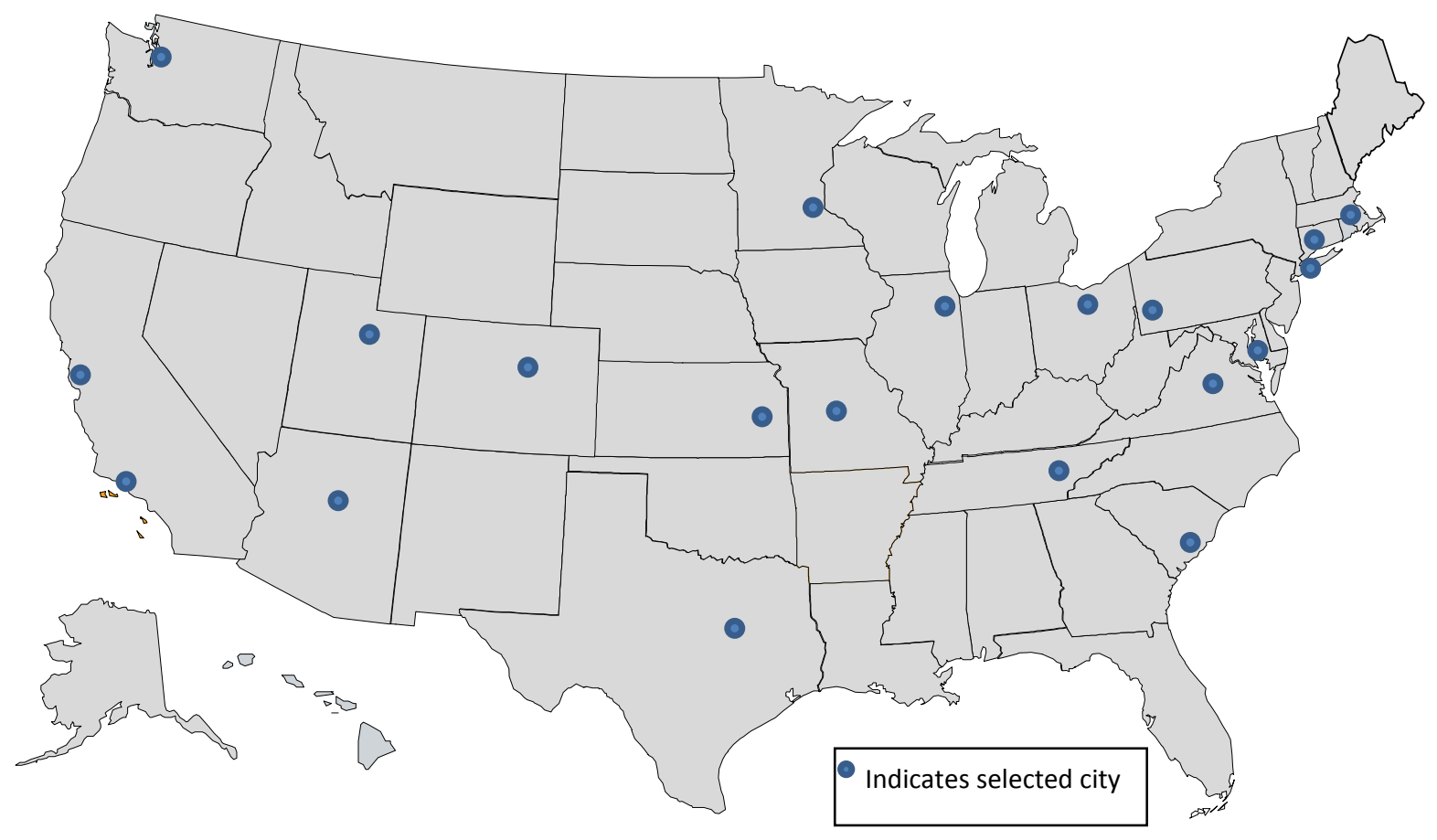

Figure 2. Selected cities

\subsubsection{Climate Action and Sustainability Plans, Sustainability Websites, and Dashboards}

Publically available sustainability, climate, GHG inventory reports, and in some cases sustainability dashboards found on city websites were used as the primary sources of information to understand goals, actions, and the metrics cities track over time. Goals and actions related to energy were cataloged according to the framework in Figure 1. Typically, plans clearly articulate broad goals and specific actions that correlate with each category in the analysis framework; if goals could not be identified within the text, they were left blank. In the rare absence of a formal sustainability plan or CAP, or in addition to these plans, analysts referred to goals listed on city sustainability sites.

City plans often group actions in relevant categories or chapters (i.e., energy, buildings, and transportation). Figure 3 is an example of three goals and subsequent actions from the energy efficiency and clean energy section of Chicago's sustainability plan. 


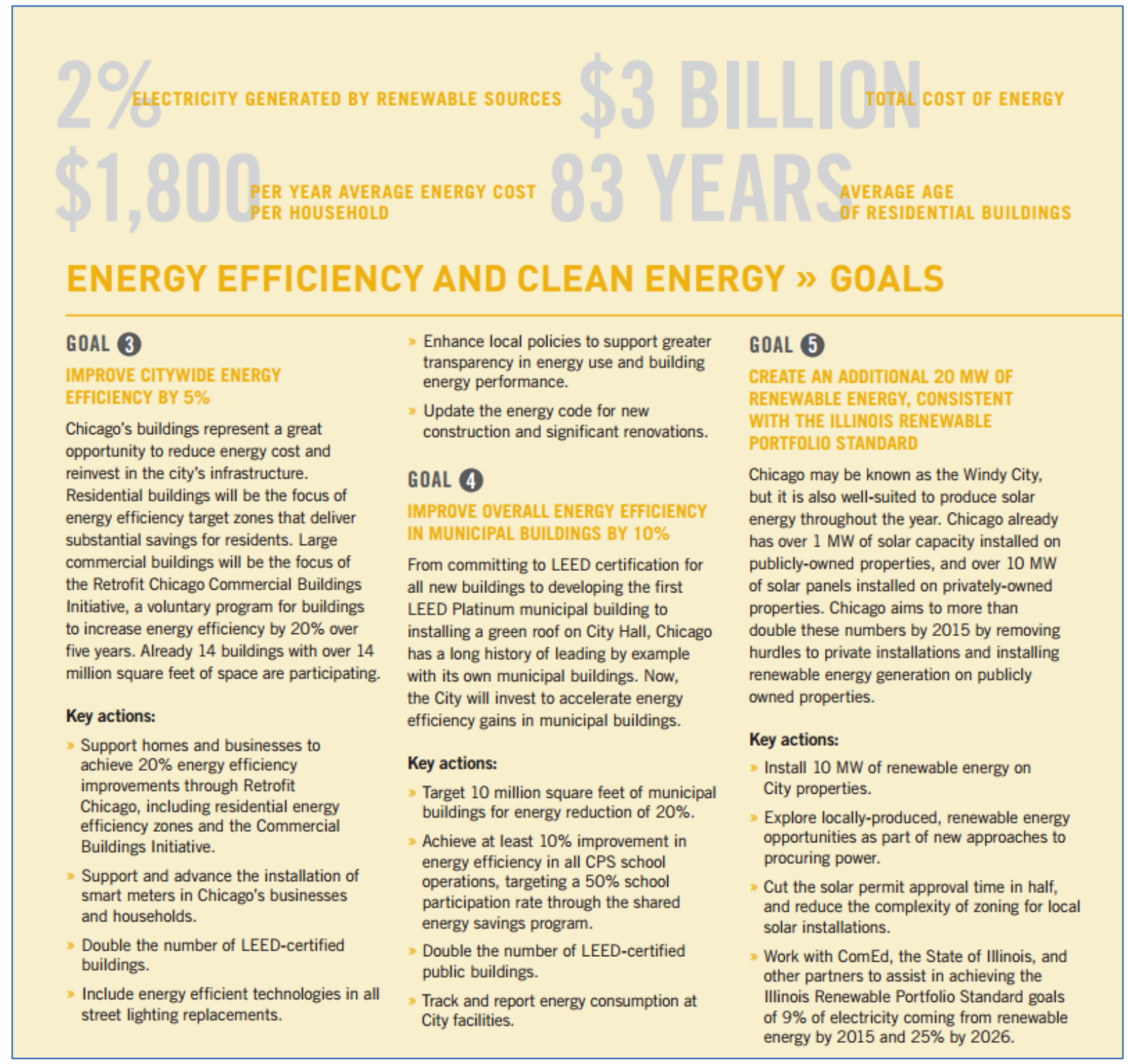

Figure 3. Example of city goals and actions ${ }^{5}$

\subsubsection{Interviews With City Staff}

Analysts conducted phone interviews with city sustainability staff to better understand the energy-related goals cities have and which actions and programs cities want to implement. Interviews focused on each city's processes, successes, and challenges associated with setting and measuring progress toward energy goals outlined in city CAPs and sustainability plans. Interviews provided context and supplemented findings from CAPs and sustainability plans and helped shape an understanding of the role of leadership in the context of a city's goals and actions. Representatives of some cities could not be reached for interviews. ${ }^{6}$

\footnotetext{
${ }^{5}$ Source: Sustainable Chicago Action Agenda (2015)

${ }^{6}$ Three of the 20 cities selected for this analysis did not respond to interview requests.
} 


\subsubsection{CAP and Sustainability Data Standardization}

Raw data was collected from city CAPs and sustainability plans, websites, and dashboards, to create a set of standardized actions, goals, and metrics. A Microsoft Access database was used to match specific city goals, actions, and metrics with standardized actions, goals, and metrics. Although some specificity is lost in the standardization process, a generic nomenclature that facilitates comparison across cities emerges.

\section{Standardized Goals}

City energy-related goals run the gamut from specific to general. City goals were standardized and grouped into high-level categories and subcategories. Because the nature of goals differs from actions, they are categorized differently than actions. Table 5 shows common themes in city energy-related goals. For more details, see Appendix B, Table B-2.

Table 5. Standardized Energy-Related Goal Categories and Subcategories

\begin{tabular}{|c|c|}
\hline Category & Subcategory \\
\hline Buildings & $\begin{array}{l}\text { Building Energy Use } \\
\text { Codes and Standards }\end{array}$ \\
\hline Renewable Power & $\begin{array}{l}\text { Electricity Supply } \\
\text { Technology Specific }\end{array}$ \\
\hline Transportation & $\begin{array}{l}\text { Land Use } \\
\text { Mobility } \\
\text { Vehicles } \\
\text { Fuels }\end{array}$ \\
\hline Energy and Emissions & $\begin{array}{l}\text { Emissions } \\
\text { Overall Energy Consumption }\end{array}$ \\
\hline Sustainability & $\begin{array}{l}\text { Education and Outreach } \\
\text { Community and business sustainability }\end{array}$ \\
\hline Efficiency & Energy Use \\
\hline
\end{tabular}

This categorization maps energy consumption, GHG emissions, and sustainability goals along with sector-specific goals in Buildings and Efficiency, Renewable Power, and Transportation. The Energy and Emissions category primarily addresses goals that are not associated with a particular sector, but are instead aimed at reducing overall energy consumption and GHG emissions in cities. The Sustainability category goals tend to focus on education and outreach and achieving a sustainable environment. Sector-specific goals in the Buildings category address energy consumption and reduction in buildings and work toward implementing more stringent building energy codes. Renewable Power goals mainly aim to increase renewable energy power supplied to a city. Goals under the Transportation category are varied and mainly address transport-related land use development, pedestrian, bicycle, and public transport issues, and vehicle emissions and fuel reduction. 


\section{Standardized Actions}

Sustainability plans and CAPs typically group actions by sector or targeted audience (e.g., municipal government or business community). For standardization purposes, actions are grouped into five overarching categories based on a synthesis of the plans analyzed; within each category, several subcategories represent a more disaggregated version of the most common kinds of actions cities aspire to undertake (see Table 6). For more details, see Appendix B, Table B-1.

Table 6. Standardized Energy-Related Action Categories and Subcategories

\begin{tabular}{ll}
\hline \multicolumn{1}{c}{ Category } & \multicolumn{1}{c}{ Subcategory } \\
\hline & Building Codes, Standards, and Certification \\
& Building Upgrades and Improvements \\
& Heating and Fuels \\
Buildings and Efficiency & Information and Transparency \\
& Leading by Example \\
& Market Investment and Financing \\
& Support and Planning \\
\hline \multirow{2}{*}{ Electricity Supply and Infrastructure } & Conservation and Efficiency \\
\hline & Infrastructure and Generation \\
\hline \multirow{3}{*}{ Municipal Operations and Programs } & Built Environment \\
& Community Outreach and Education \\
& Emissions Goal Setting \\
& Information and Transparency \\
& Operational Policies and Support \\
\hline \multirow{3}{*}{ Renewable Power } & Codes and Permitting \\
& Incentives and Financing \\
& Local Power Generation \\
& Supporting \\
\hline & Alternative Transit Incentives and Pricing \\
& Codes, Laws, and Enforcement \\
& Freight and Airports \\
Transportation and Land Use & Funding and Programs \\
& Improved Transportation Options and Infrastructure \\
& Municipal Fleet and Freight \\
& Planning \\
\hline
\end{tabular}

\section{Standardized Metrics}

Cities use metrics (often called indicators) to measure progress toward their goals. Metrics vary by the extent to which they are tracked, the length of time they are tracked, and the means with which they are tracked. The common metrics highlighted in Figure 12, therefore, are based only on cities that actually tracked these metrics; 2 of the 20 profiled cities have no evidence of publically available energy-related metrics. Table 7 shows the general categories and subcategories under which most city metrics fell. For more information, see Appendix B, Table B-3. 
Table 7. Standardized Energy-Related Metric Categories and Subcategories

\begin{tabular}{ll}
\hline \multicolumn{1}{c}{ Category } & \multicolumn{1}{c}{ Subcategory } \\
\hline Buildings and Efficiency & $\begin{array}{l}\text { Energy Consumption } \\
\text { Green Buildings }\end{array}$ \\
\hline Renewable Power & $\begin{array}{l}\text { Electricity Supply } \\
\text { Technology Specific }\end{array}$ \\
\hline \multirow{2}{*}{ Transportation and Land Use } & $\begin{array}{l}\text { Bike and Pedestrian Infrastructure } \\
\text { Mobility } \\
\text { Vehicles and Fleets }\end{array}$ \\
\hline \multirow{2}{*}{ Energy and Emissions } & Community-Wide Emissions \\
\hline Economic Development & Community-Wide Energy Consumption \\
\hline
\end{tabular}

Metrics under Energy and Emissions measure community-wide energy consumption and GHG emissions. Economic Development metrics mostly pertain to measuring progress in sustainable businesses $^{7}$ and clean energy jobs. Within Renewable Power, a distinction was made based on whether the metrics are for a particular technology or are more general and emphasize renewable energy contribution to electricity supply. Transportation captures subcategories for bike and pedestrian infrastructure, mobility (particularly public transport), alternative commute ridership, vehicle miles traveled, and transit-oriented land use development; vehicles and fleets focused primarily on fuel use, alternative fuel vehicles, and number of vehicles used.

\subsubsection{Challenges and Limitations}

This analysis does not capture energy-related goals and activities in every U.S. jurisdiction, nor does it make overarching claims about cities and energy; the results should not be overgeneralized. Variability in structure, content, language, continuity, and specificity of plans, reports, and updates posed challenges to interpreting plans according to the conceptual framework. Though this analysis measures frequency of actions, goals, and metrics, it is important to acknowledge the content and quality of plans. Equating quantity with quality favors lengthy plans that may not be comprehensive or as effective as more succinct plans.

This analysis focused primarily on publically available sources, but cities may actually be creating energy-related goals, implementing energy-related actions and programs, and measuring progress in ways not captured in their plans or annual reports. Timing can make a difference in types of actions, goals, and the metrics that cities publically report. During this analysis, three of the sampled cities (Fort Collins, Boston, and Los Angeles) released updated CAPs and reports ${ }^{8}$.

\footnotetext{
${ }^{7}$ Typically those who have obtained some type of "sustainable" or "green" certification.

8 These new CAPs are not captured in this analysis due to timing.
} 


\section{Findings}

Section 4.1 summarizes the different practices cities use to plan, implement, and measure energy decisions. A look at how GHG inventories inform the creation of CAPs, sustainability plans, and energy-related policymaking in general, follows. Findings are then presented for city actions, goals, and metrics separately, followed by an analysis of how all three work together.

\subsection{Planning and Implementing Energy Decisions}

Cities adopt - to varying degrees and competencies - common practices as they make energy decisions. Cities that lead in plan implementation ${ }^{9}$ show a clear link between GHG inventories and CAPs and sustainability plans. In these cities, inventories and plans are updated regularly; progress is measured based on energy-related metrics and reported regularly. Table 8 summarizes these common practices where goals, actions, and metrics are clearly linked.

Table 8. Common Practices From In-Depth Cities: Planning, Implementing, and Measuring Energy Decisions

\begin{tabular}{ll}
\hline GHG Inventory & $\begin{array}{l}\text { Establishes a baseline from which to prioritize actions and measure progress } \\
\text { Informs sustainability or climate action plan } \\
\text { Updated periodically }\end{array}$ \\
\hline $\begin{array}{l}\text { Sustainability } \\
\text { Plan/CAP/Energy Plan }\end{array}$ & $\begin{array}{l}\text { Outlines specific actions and how they relate to goals } \\
\text { Attributes GHG savings to specific actions, suites of actions, or goals }\end{array}$ \\
\hline \multirow{3}{*}{ Metrics/Indicators } & $\begin{array}{l}\text { Used to measure and track progress } \\
\text { Published regularly in reports, updates, or online sustainability dashboards } \\
\text { Clearly displayed in a designated report section (i.e., not in a narrative of } \\
\text { highlights or case studies) }\end{array}$ \\
\hline & $\begin{array}{l}\text { Completed at appropriate intervals (often annually for sustainability plans, } \\
\text { less frequently for CAPs) } \\
\text { Clan Updates }\end{array}$ \\
& Include information about the implementation stage of different actions \\
\hline
\end{tabular}

GHG inventories provide baseline data that inform the creation and emphasis of CAPs and sustainability plans. Cities that conduct regular GHG inventories report that inventories provide an indication of whether current programming is helping cities reach GHG targets and often trigger updates to CAPs (Smith and Phelan 2015; Blackmon 2015; Joseph 2015). Conducting GHG inventories provides cities with a credible foundation for advocating for energy and climate programming (Riddervold 2015).

\footnotetext{
${ }^{9}$ These cities appear to have greater resources available for planning and longer histories of plan implementation.
} 
GHG inventories help illustrate where GHG emissions and energy expenditures can be reduced in municipal governments and communities (see sidebar, Flagstaff GHG Inventory and sidebar, GHG Inventories in Knoxville). Table 9 shows which sector was the largest contributor to community-wide GHG emissions, according to each city's most recent GHG inventory. In surveyed cities with inventories, commercial and industrial buildings contribute most heavily to community-wide GHG emissions. These are followed by the transportation sector. Whether a city decides to focus initiatives primarily in the sector that most heavily contributes to GHG emissions depends on factors such as the city's level of influence over the sector, political priorities, and economic considerations (Gill 2015; Porteshawver 2015; Buffaloe 2015).

Some cities struggle to effect change in sectors where emissions are high, such as the commercial and industrial sectors, and spend more effort targeting sectors that contribute less to energy use and GHG emissions but prove more politically expedient to address (Porteshawver 2015; Riddervold 2015). Even cities that have significantly reduced GHG emissions acknowledge that larger forces beyond a city's control, such as changes in emissions factors ${ }^{10}$ or participation in regional policies, ${ }^{11}$ can contribute much more to emission reductions than specific city-led efforts in a given sector (Blackmon 2015).

The extent to which GHG inventories inform policymaking in municipal operations and how they inform the broader community sometimes differs. For example, GHG impacts of policies can guide conversations and help focus efforts on the community side, but actions are often driven by opportunity (Gill 2015; Porteshawver 2015; Williams 2015). Over time, the challenge of obtaining comparable and consistent data for GHG inventories can cause communities to lose interest and trust in using inventories to directly inform policymaking (Williams 2015). Therefore, the results of GHG inventories are among the many factors that may impact community-level energy decision making.

While some cities intend to create GHG inventories more regularly (Firestone 2015), others report that interest has shifted from global climate change mitigation to local climate change adaptation via resiliency implementation frameworks (Woodman 2015). Similarly, interest in updating CAPs has waned in some communities (Randel 2015). City staff attribute these shifts to a variety of factors, including changes in local and state political climates, lack of confidence in their ability to accurately monitor climate data, turnover among stakeholder leadership, and the emergence of new priorities from constituents and city leaders (Woodman 2015; Randel 2015).

\footnotetext{
${ }^{10}$ As utilities, such as those serving Boston, switched from coal to natural gas (i.e., a less carbon-intensive energy supply).

${ }^{11}$ For example, the Regional Greenhouse Gas Initiative.
} 
Table 9. Largest Sector Contributor to GHG Emissions in Sampled Cities ${ }^{12}$

\begin{tabular}{|c|c|c|}
\hline City & $\begin{array}{l}\text { Latest GHG } \\
\text { Inventory } \\
\text { (year) }\end{array}$ & $\begin{array}{l}\text { Largest Contributor to GHG Emissions } \\
\text { (community-wide)* }\end{array}$ \\
\hline Benicia & 2010 & Industrial and commercial \\
\hline Flagstaff & 2010 & Transportation \\
\hline Fort Collins & 2011 & Electricity (by source); residential (by sector) \\
\hline Los Angeles & 2004 & Transportation \\
\hline Park City & 2007 & Transportation (mostly airline travel) \\
\hline Seattle & 2012 & Road transport \\
\hline Chicago & 2010 & Building energy \\
\hline Cleveland & 2010 & Industrial emissions \\
\hline Columbia & 2010 & Energy (sector) \\
\hline Minneapolis & 2010 & $\begin{array}{l}\text { Electricity consumption (by source); commercial/Industrial } \\
\text { buildings (sector) }\end{array}$ \\
\hline Mission & 2005 & Transportation \\
\hline Charlottesville & 2011 & Commercial/Institutional \\
\hline Pittsburgh & 2008 & Commercial \\
\hline Dallas & 2010 & Electricity (source) \\
\hline Boston & 2014 & Commercial \\
\hline Charleston & 2006 & $\begin{array}{l}\text { Buildings (includes residential, commercial, government, } \\
\text { and industrial) }\end{array}$ \\
\hline Baltimore & 2007 & $\begin{array}{l}\text { Industrial (only marginally higher than commercial, } \\
\text { residential, and transportation sectors) }\end{array}$ \\
\hline Knoxville & 2005 & Transportation \\
\hline New York City & 2013 & Buildings \\
\hline Hartford & $\mathrm{N} / \mathrm{A}$ & $\mathrm{N} / \mathrm{A}$ \\
\hline
\end{tabular}

*Direct terminology used from city inventories

Energy and climate planning takes place in the broader, more complex environment of local decision making - a complex process affected by constituent concerns, priorities, budgets, legal obligations, and more. While a city may excel at some of the clearly linked planning practices

\footnotetext{
${ }^{12}$ Sources: Climate Action Plan Introduction: Benicia (2009); Fort Collins Climate Action Plan Status Report (2011); Chicago Regional Greenhouse Gas Emissions Inventory (2010); Minneapolis Climate Action Plan (2013); City of Mission GHG Inventory (2008); Charleston Green Plan Inventory \& Metrics (2009); Greenovate Boston (2014); Charlottesville Emissions Reports (2008, 2012); City of Columbia Greenhouse Gas Inventory (2010); Seattle Community Greenhouse Gas Emissions Inventory (2012); City of Flagstaff Community Greenhouse Gas Emissions Reports (2009, 2010); City of Dallas Greenhouse Gas Emissions Inventory (2012); City of New York, Inventory of Greenhouse Gas (2013); Knoxville Energy Inventory (undated); City of Baltimore Greenhouse Gas Emissions Analysis (2009); Community Carbon Footprint (Park City) (2015); Climate LA (2007).
} 


\section{CAP Integration in Pittsburgh}

During the first iteration of the

Pittsburgh Climate Action Plan in

2008 , the Office of Sustainability had

few other city plans to reference. In

2015, Pittsburgh has an opportunity

for integration as the city works on five

plans (comprehensive, hazard

mitigation, innovation roadmap,

climate action and resilience, and a

city-wide green infrastructure plan).

The leadership for each plan aims to

work collaboratively, create integration

opportunities, and make sure that the

plans reference each other holistically

(Ervin 2015).

\section{CAP in Seattle}

The process of creating the city's climate action plan in Seattle involved connecting with and building capacity among city staff, stakeholders, and agencies, which have been key contributors to enabling the integration of the climate action plan into other city plans (Mallory and Morgenstern 2015). outlined in Table 1, the integration of energy-related plans into other city planning and decision making impacts whether these plans effect measurable change.

The integration of CAPs and sustainability plans into other city planning and decision making appears to become more robust over time in most cities (see sidebar, CAP Integration in Pittsburgh and sidebar, CAP in Seattle). Several cities report that energyrelated goals outlined in CAPs and sustainability plans are reflected in other strategic planning efforts (Blackmon 2015; Smith and Phelan 2015; Ervin 2015; Riddervold 2015; Joseph 2015).

At the same time, city staff often report that their CAPs and sustainability plans may not be used intentionally in decision making, but the values of the plans still inform case-by-case decision making (Randel 2015; Williams 2015). Shifting from acceptance of high-level sustainability principles to operationalizing sustainability remains a work in progress for most cities (Abbott 2015). Sometimes participation in a new program or challenge, such as the Georgetown University Energy Prize, creates a sudden, strong motivator for incorporating energy goals into overall city planning (Buffaloe 2015) and measuring progress (Riddervold 2015). Updating any city strategic plan is a time- and labor-intensive effort; often the timing and sequencing of multiple plan

updates stymie excellent integration of CAPs and sustainability plans into other strategic planning (Smith and Phelan 2015).

\subsection{City Actions}

Once energy use and GHG emission baselines are established in GHG inventories, cities typically use this information to prepare sustainability or climate plans that lay out specific actions for reducing energy use and GHG emissions. This analysis examined sustainability and climate plans and interviewed city staff to understand trends in city energy-related actions.

According to city staff interviews, several cities (Chicago, Pittsburgh, Mission, Benicia, Minneapolis, Los Angeles, and Boston) are targeting the commercial building sector, which contributes significantly to a city's carbon footprint. Others (e.g., Seattle and Charleston) are focused largely on the transportation sector, from both transportation modes and land use perspectives (Ervin 2015; Randel 2015; Porteshawver 2015; Prest 2015; Mallory and Morgenstern 2015; Woodman 2015; Firestone 2015; Blackmon 2015). Standardizing and grouping actions from city sustainability plans and CAPs shows that most (42\%) city actions fall 
within the Transportation and Land Use category, followed by the Buildings and Efficiency category $(26 \%){ }^{13}$

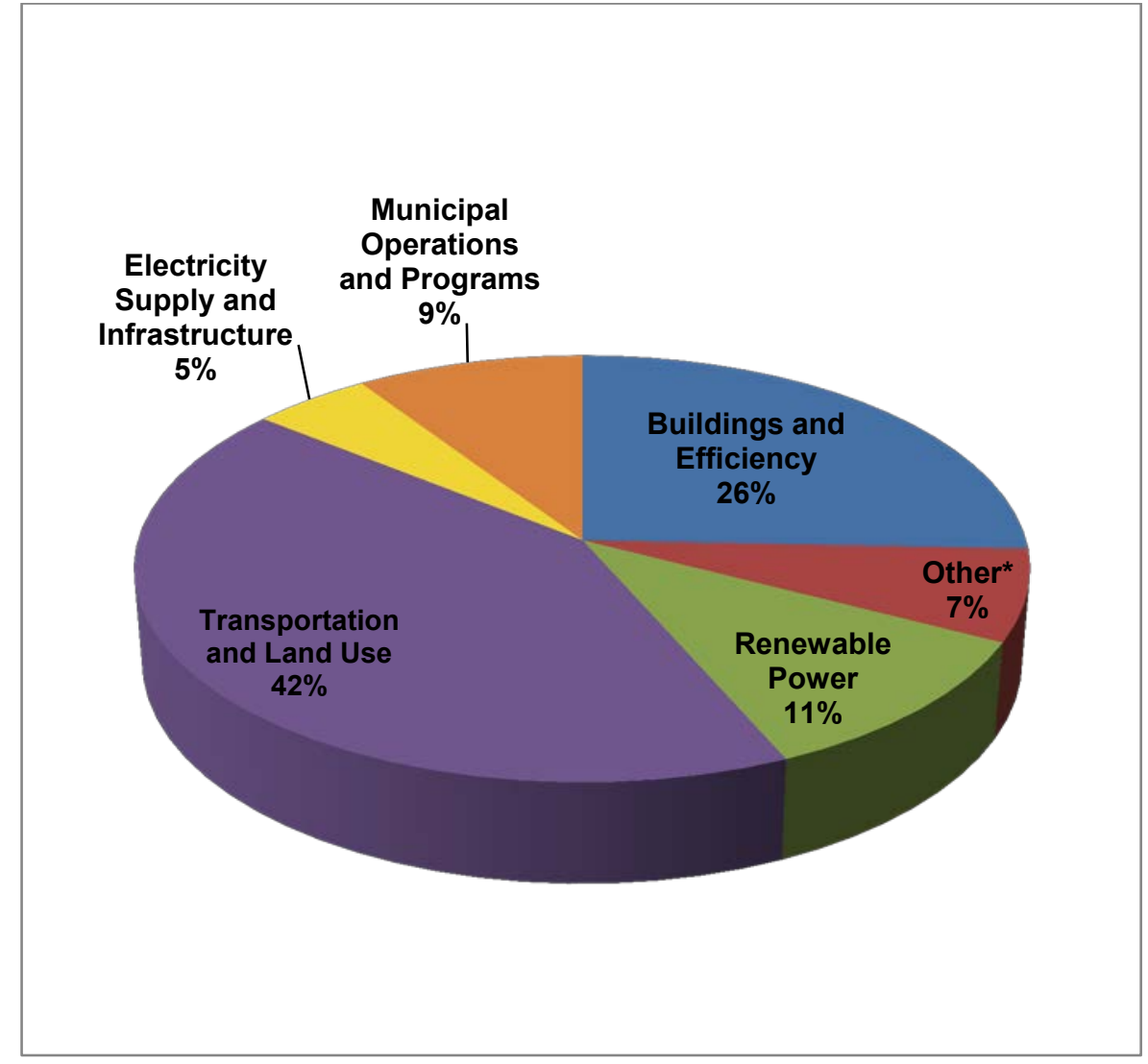

Figure 4. Summary of standardized actions by category

*The "other" category represents actions such as climate adaptation, creation of GHG emission plans, joining sustainable city and business organizations, and sustainability/environmental education.

When the categories and subcategories are set aside and standardized actions are examined individually, building certifications and best practices is the most common action, followed by outreach and communication (which could be in support of any of the categories), and walkable, complete, mixed-use community planning (Figure 5). For more detail on actions categorizations, see Appendix B, Table B-1.

\footnotetext{
${ }^{13}$ Results captured in Figure 4 speak to the frequency and diversity of city actions highlighted in plans but have no bearing on which sector a city directs funding and human resources to at any given time. Clearly, Transportation and Land Use is a sector cities aspire to impact significantly; whether those aspirations align with efforts on the ground depends on other factors brought up in interviews with city staff.
} 


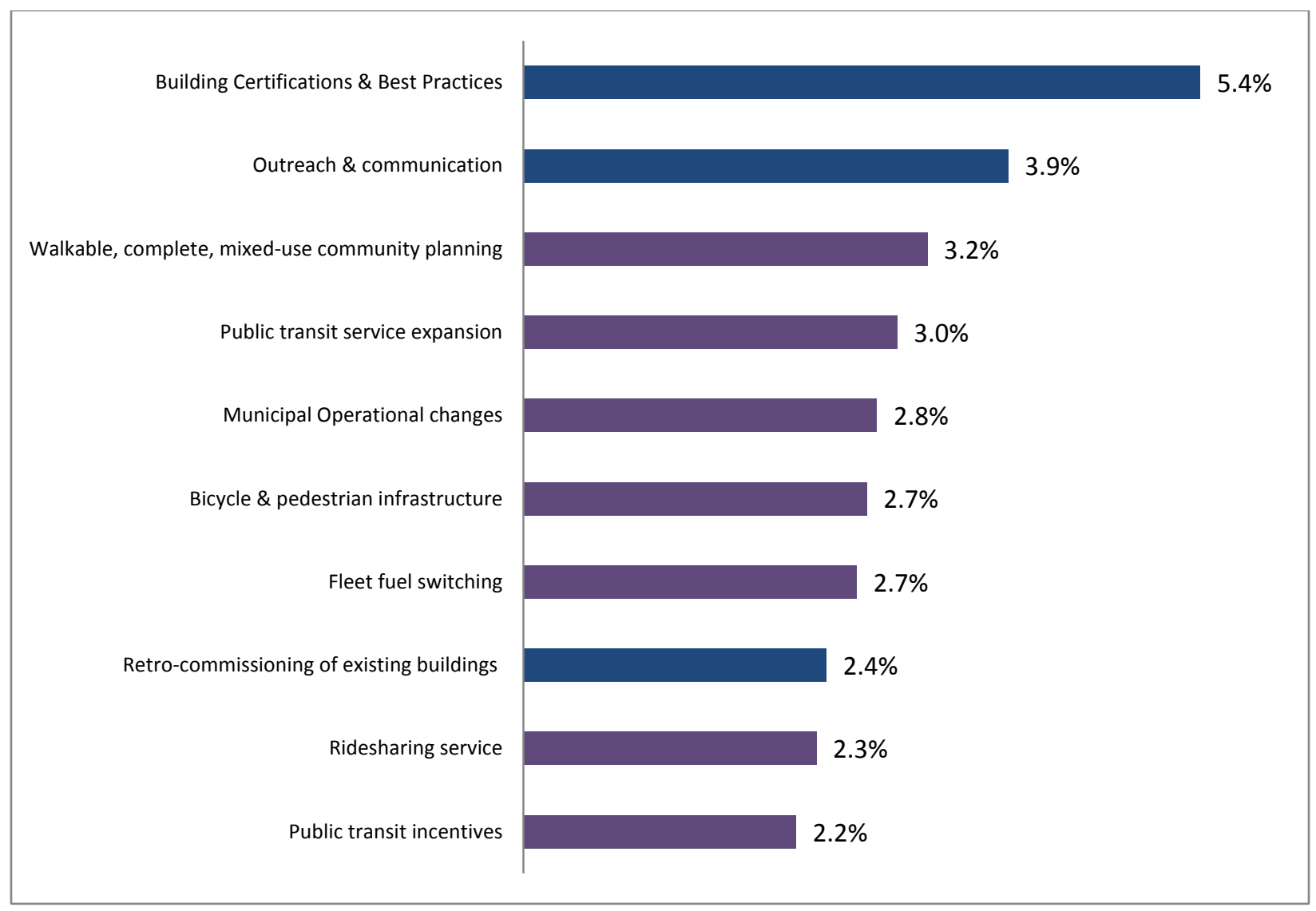

Figure 5. Top 10 city standardized actions (as a percent of total actions)

Building certifications and best practices actions include requiring various levels of Leadership in Energy \& Environmental Design (LEED)-certified buildings, net zero energy buildings, and standards for greening historic buildings. Interestingly, cities do not commonly report taking these actions to reduce community-wide energy consumption in the ICMA survey, where the most commonly reported action is weatherization programs for individual residences (see Table 1) (ICMA 2010). Such a differentiation underscores the difference between actions on the ground (in 2010) and city plans.

Walkable, complete, mixed-use community planning is the leading type of action in the Transportation and Land Use category (Figure 6). Some examples of this kind of action include creating a "complete streets" ordinance, designating underutilized land for mixed-use development, and developing "green zones." The most common reported action city governments take in the ICMA survey is adding biking and walking trails. Although not the most common action according to this analysis, results indicate that biking and walking infrastructure is still a popular aspirational action (Figure 6) and could even be considered a subset of walkable, complete, mixed-use community planning. ${ }^{14}$

\footnotetext{
${ }^{14}$ This analysis equates the ICMA's "add biking and walking trails" to the standardized action of bicycle and pedestrian infrastructure.
} 


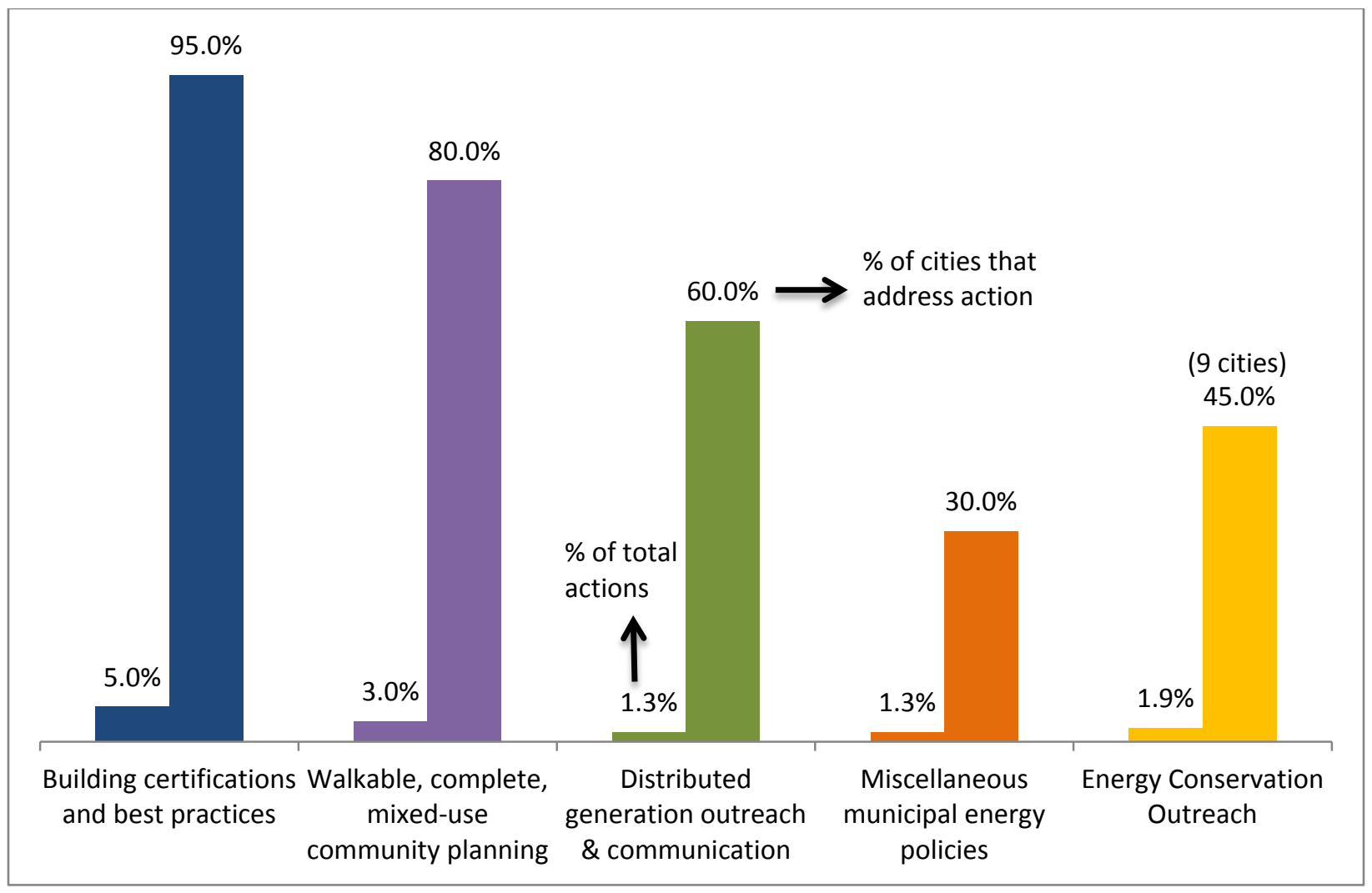

Figure 6. Top standardized action by category (percentage of total actions shown and percentage of cities that address action)

\section{Category Key:}

\section{Buildings \& $\quad$ Transportation \& $\quad$ Renewable Municipal Operations $\quad$ Electricity Supply \& Efficiency Land Use Power \& Programs Infrastructure}

*Many cities have separate municipal sustainability and climate action plans that are not captured in this estimate; thus this number of cities is likely an underestimate.

Even within community-focused sustainability plans and CAPs, cities emphasize an assortment of actions targeted at municipal operations (see Figure 6). Although the Municipal Operations and Programs category of actions represents only $9 \%$ of the total city actions in our sample (see Figure 4), many cities have separate plans for municipal operations that may not be captured in this analysis. ${ }^{15}$

Cities are focusing on improving energy efficiency, increasing renewable energy, and decreasing GHG emissions within their own municipal operations because they want to "lead by example" and because cities can assert more control over their own operations than over the community at

\footnotetext{
${ }^{15}$ This analysis used primarily community-focused or community-municipal combination plans, rather than specific municipal plans. However, in the absence of a preferred plan, analysts depended on whatever plans were availableoften municipal-only plans.
} 
large (Ervin 2015; Woodman 2015; Natarajan 2015; Gill 2015). Actions in this category vary widely, as evidenced by the ranking of miscellaneous municipal energy policies actions as the most prevalent type of action (Figure 6). The second most common action targeted at municipal operations is the installation of light-emitting diode (LED) traffic signals and streetlights. Examples of miscellaneous municipal energy policies include eliminating excess appliances in municipal buildings, amending air travel policies, and instituting "lights-off" policies. The Municipal Operations and Programs category includes a wider range or actions relative to the other categories.

For Renewable Power initiatives, cities are overwhelmingly focusing on Distributed Generation Outreach and Communication (see Figure 6). This type of action includes incentivizing and financing distributed generation and providing better information to residents and businesses interested in distributed generation (primarily solar). Compared to other common actions, Distributed Generation Outreach and Communication represents only 1.3\% of total actions; this finding, combined with its low ranking in the ICMA survey ${ }^{16}$ (Table 2) indicates impacting renewable power levels at the community level may be particularly challenging for cities.

Cities mention the fewest activities in the Electricity Supply and Infrastructure sector, likely due to the perception that cities without a municipal utility have limited ability to impact energy markets and electricity regulation. In this category, cities emphasize the continuation or expansion of energy efficiency outreach (Figure 6) - a more achievable objective than improving or retiring generation facilities. Despite the challenges associated with targeting a community's energy supply, Minneapolis worked with its state government and regional utilities to influence its energy supply mix and thus fulfill city-level energy priorities (see sidebar, Clean Energy Partnership in Minneapolis).

\section{Clean Energy Partnership in Minneapolis}

To achieve Minneapolis's carbon goals, city staff has had to think outside the box-that is, literally outside the area under the city's jurisdictional control. Xcel Energy's (the investor-owned electric utility serving Minneapolis) future generation mix and power system has significant impacts on the city's GHG emissions profile, information critical for planning city-wide energy-related programming and policies.

Minneapolis leveraged the 2014 expiration of its franchise agreement with Xcel Energy and CenterPoint Energy (the natural gas utility) to negotiate for cleaner energy, resulting in the groundbreaking city and utility Clean Energy Partnership (Jossi 2014).

Minneapolis also found that engaging in public utility commission (PUC)

proceedings at the state level is an effective way for the city to advocate for greater incorporation of renewable energy sources into Xcel's generation mix.

An understanding of how cost and reliability considerations factor into decision making is critical for asking effective questions at the PUC. In this vein, the state of Minnesota ordered its own engineering analysis of renewable energy integration impacts on the transmission system due to its interest in increasing the state RPS to $40 \%$ by 2030. The study provided an additional perspective in PUC proceedings where technical studies of this caliber are typically provided by the utility (Prest 2015).

\footnotetext{
${ }^{16}$ The equivalent ICMA action could be considered "Installation of solar equipment" for residences and businesses.
} 
Cities with unique economies or populations, such as Park City and Columbia, prioritize sectors not emphasized by other cities with more diverse economies (see sidebar, Energy Actions in Park City). For example, as a college town with a large transient population, Columbia emphasizes residential energy efficiency, particularly among the large rental population (Buffaloe 2015). Several cities also spoke about the need to target CAP programming and track metrics at the neighborhood level, and not just overarching energy sectors (Natarajan 2015; Prest 2015; Buffaloe 2015). Using a neighborhood-level lens allows cities to measure and address equity concerns within the city energy realm (Prest 2015).

Cities may also engage in energy-related activities not specified in plans, taking advantage of opportunities that arise and align with overall energy goals (Gill 2015). Many of these opportunities for action in college towns such as Columbia and Pittsburgh arise from leveraging partnerships with the local university (Buffaloe 2015; Ervin 2015).

\section{Energy Actions in Park City}

When it comes to community-wide energy actions, Park City targets resorts and nightly rentals (e.g., hotels and Airbnb)-a large contributor to community-wide energy use when this ski town's population explodes during the winter tourism season.

Because of Park City's economic reliance on tourism, the city also includes airline travel its community-wide GHG inventory, even though this is not a common practice in city inventories. Within municipal operations, Park City focuses energy reduction efforts on its water treatment plant, which is responsible for $50 \%$ of the municipal government's energy use (Abbott 2015).

\subsection{City Actions and Greenhouse Gas Emissions Abatement}

Plans demonstrate significant disparities in their levels of quantification and measurement. Of the 20 profiled cities, only 9 clearly and systematically reported the GHG abatement potential of actions, which is expressed as a percent contribution to fulfilling an overall GHG reduction target. The remaining cities either do not tie any GHG abatement potential to actions or do so for only some actions. Of the 9, most estimate that the sum of actions within the Renewable Power ${ }^{17}$ and Buildings and Efficiency categories have high estimated GHG abatement potential (Table 10). More than half consider the sum of actions within the Transportation and Land Use category to have low GHG abatement potential. However, some exceptions, such as Seattle, consider Transportation and Land Use actions to have high GHG abatement potential.

\footnotetext{
${ }^{17}$ These category names have also been standardized; cities may use different terminology, but the content of their categories falls within the scope of the standardized categories.
} 
Table 10. City Actions and GHG Abatement Estimates ${ }^{18}$

\begin{tabular}{|c|c|c|c|}
\hline CAP Category & High: $>50 \% *$ & Medium: $25 \%-49 \%$ & Low: $<24 \%$ \\
\hline \multirow[b]{2}{*}{ Renewable Power } & $2.5^{\star *}$ & 4 & 1 \\
\hline & $\begin{array}{l}\text { Park City, Mission, } \\
\text { Baltimore }\end{array}$ & $\begin{array}{l}\text { Chicago, Mission, } \\
\text { Cleveland, Charleston }\end{array}$ & Minneapolis \\
\hline \multirow[b]{2}{*}{ Buildings and Efficiency } & $2.5^{\star *}$ & 4 & 3 \\
\hline & $\begin{array}{l}\text { Minneapolis, Baltimore, } \\
\text { Boston }\end{array}$ & $\begin{array}{l}\text { Chicago, Cleveland, } \\
\text { Charleston }\end{array}$ & $\begin{array}{l}\text { Park City, Seattle, } \\
\text { Mission }\end{array}$ \\
\hline \multirow[b]{2}{*}{$\begin{array}{l}\text { Transportation and } \\
\text { Land Use }\end{array}$} & 1 & 2 & 5 \\
\hline & Seattle & Charleston, Boston & $\begin{array}{l}\text { Park City, Chicago, } \\
\text { Cleveland, Minneapolis, } \\
\text { Baltimore }\end{array}$ \\
\hline
\end{tabular}

*I.e. more than half of abatement potential is expected to come from this category.

**Baltimore's CAP has an "Energy savings and Supply" category whose actions are estimated to have high abatement potential. For this analysis, the category is split into two-renewable power and buildings and efficiency.

More actions are planned in the Transportation and Land Use category than any other category (Figure 4), yet many of the cities estimate this group of actions represents the lowest GHG abatement potential (Table 10). This further reflects the divide between how cities prioritize actions and their expectations of GHG impacts.

The 9 cities employ different methodologies (with varying sets of assumptions) to estimate GHG abatement potential. Numerous factors, such as electricity fuel type, population density, and climate, vary by city, and each plays a role in determining the impact a group of actions has on a city's GHG profile. The small data set (nine cities) and variability among methodologies limit the ability to draw robust associations between GHG emission reduction levels and types of actions. The paucity of cities in this sample that estimate the GHG impact of groups of actions speaks to a need for creating and standardizing methodologies to estimate the energy and GHG abatement impacts of different actions or suites of actions.

\subsection{City Goals}

City energy and climate goals are typically high-level visions for the community that help focus city government sustainability activities. Goals may not dictate specific energy-related programs and services because programs evolve over time as technologies and constituent needs change (Smith and Phelan 2015). Few cities express energy-related goals — other than GHG emission reduction goals - quantitatively. This analysis shows that like city actions, the most common types of city goals fall in the Transportation and Land Use category (37\%), followed by the Energy and Emissions category (16\%) (Figure 7). Figure 8 shows the most common goals (standardized) by category. ${ }^{19}$ Many cities express the desire to "improve energy efficiency" and "increase renewable energy," but these goals lack specificity and often cover multiple energy sectors; thus, they have been deemed "aspirational goals" (Figure 8). Common city energyrelated goals focus on reducing carbon emissions from transportation, improving community wide energy efficiency, increasing renewable energy, and increasing biking and walking.

\footnotetext{
${ }^{18}$ Sources: Park City SOS Action Plan, 2010; Mission Climate Action Plan, 2009; Minneapolis Climate Action Plan, 2013; Chicago Climate Action Plan, 2008; Cleveland Climate Action Plan, 2013; City of Baltimore Climate Action Plan, 2013; Charleston Green Plan, 2010; Sparking Boston's Climate Revolution, 2010; Seattle Climate Action Plan, 2013.

${ }^{19}$ Two goals tied for top place in the Transportation category.
} 


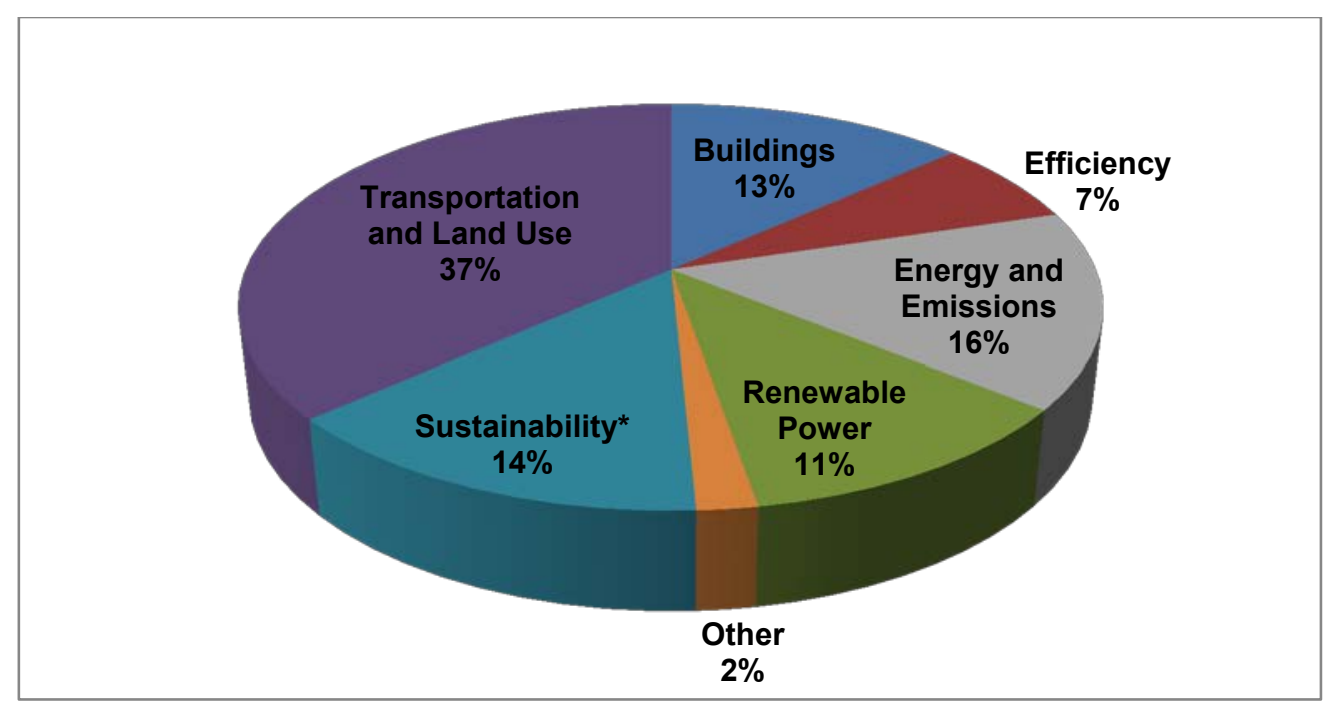

Figure 7. Summary of standardized goals by category

*Sustainability goals include expanding energy education and outreach, enhancing sustainability in general, and improving sustainability project management processes. Other (2\%) represents energy-related goals that did not correspond to other categories.

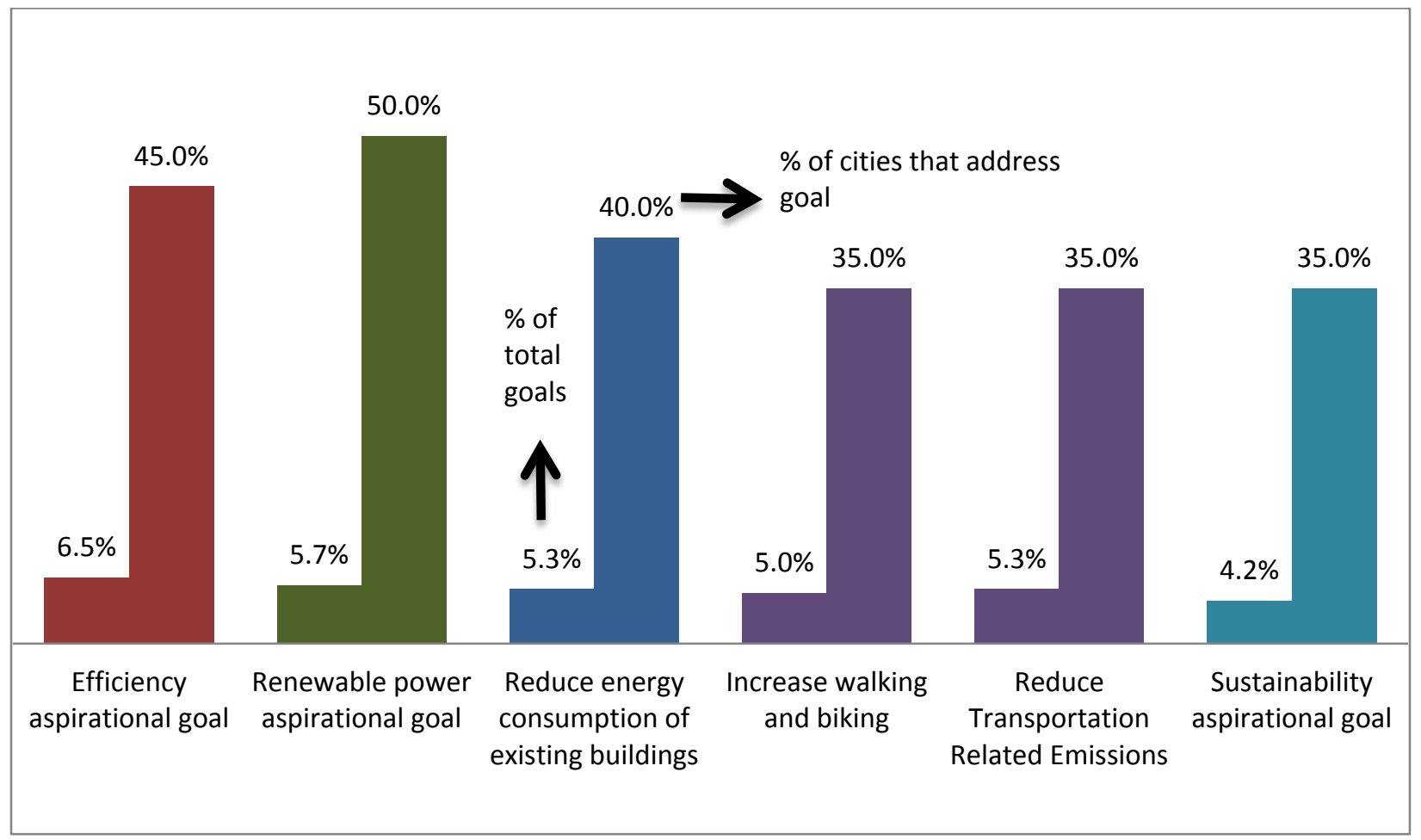

Figure 8. Top standardized goal within each category (percentage of total goals shown and percentage of cities that address goal) (excluding "other" category)

\section{Category Key:}

Efficiency Renewable Power Buildings Transportation \& Land Use Sustainability




\subsection{Measuring Progress}

The most common types of metrics cities use to indicate progress toward goals fall within roughly the same categories as the most popular action and goal categories: Transportation and Land Use and Buildings and Efficiency (Figure 9). The single most common metric is community wide GHG emissions - the only metric in the Emissions category (see Figure 10). Because selection criteria in this analysis included a city commitment to GHG emissions reduction, an emphasis on measuring progress toward this goal is expected. Figure 10 shows the five most common metrics, excluding those in the "other" category.

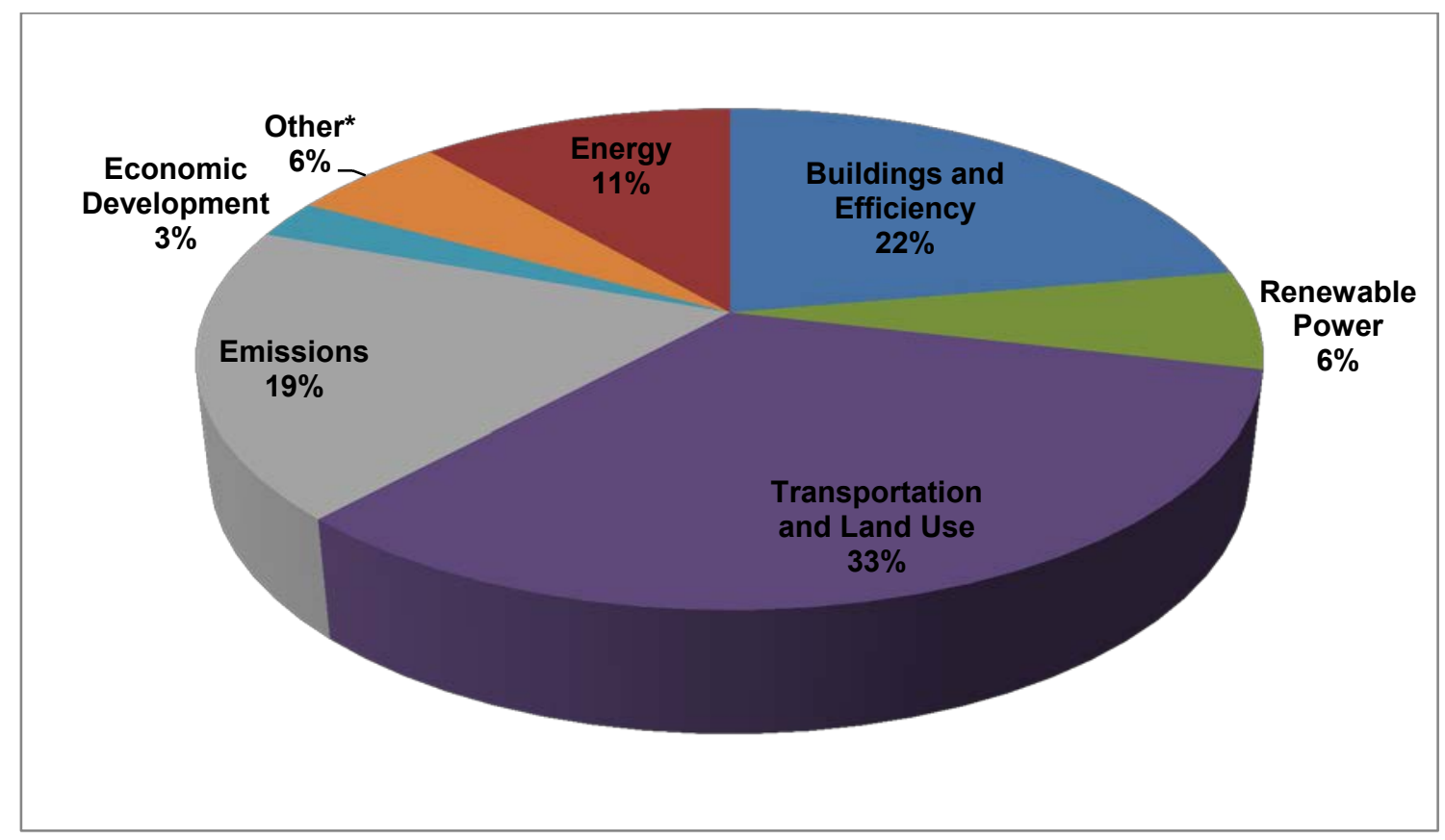

Figure 9. Summary of standardized metrics by category

* "Other" metrics are those unique to certain cities and do not fit within other categories. 


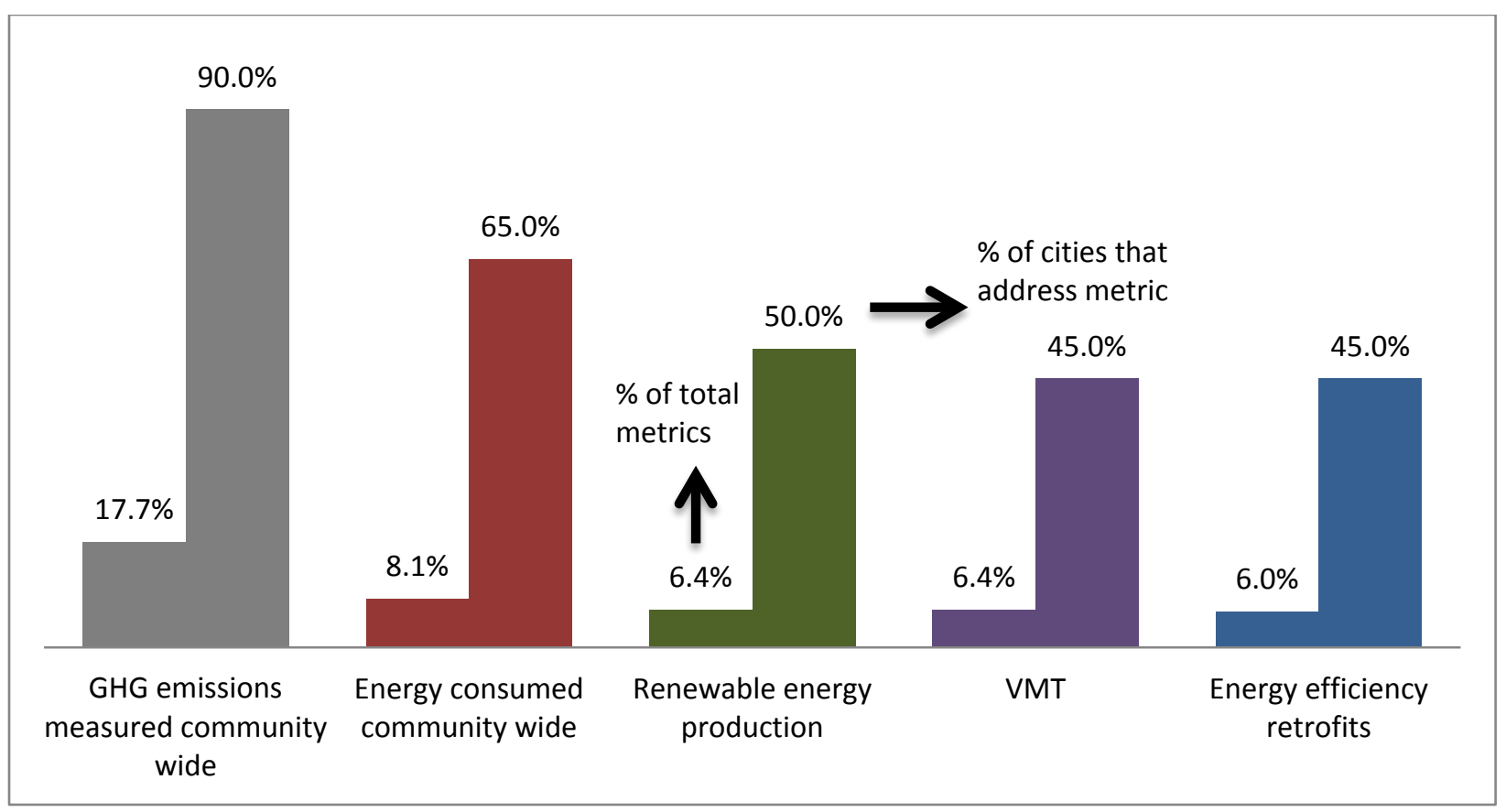

Figure 10. Top standardized metric within each category (percentage of total metrics shown and percentage of cities that address metric) (excluding "other" category)

\section{Category Key:}

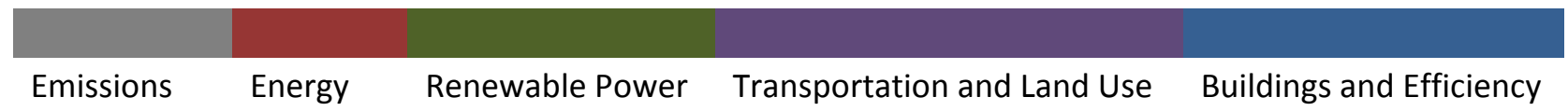

Some cities (e.g., Fort Collins, Seattle, and Los Angeles) began reporting metrics in the late 1990s and early 2000s; others began more recently. Some provide metrics in annual reports; others (e.g., Charleston and Park City) report metrics only via GHG inventories and updates every few years. Cities tend to become more sophisticated in reporting metrics over time, both in the number of metrics tracked and presentation. Other cities (e.g., Cleveland, Boston, Minneapolis, Charlottesville, and Los Angeles) have created user-friendly sustainability dashboards that display energy-related metrics in graphical form over time (see Figure 11). Some cities track the implementation progress (e.g., early, mid, implemented) toward energy-related actions (see Figure 12). 


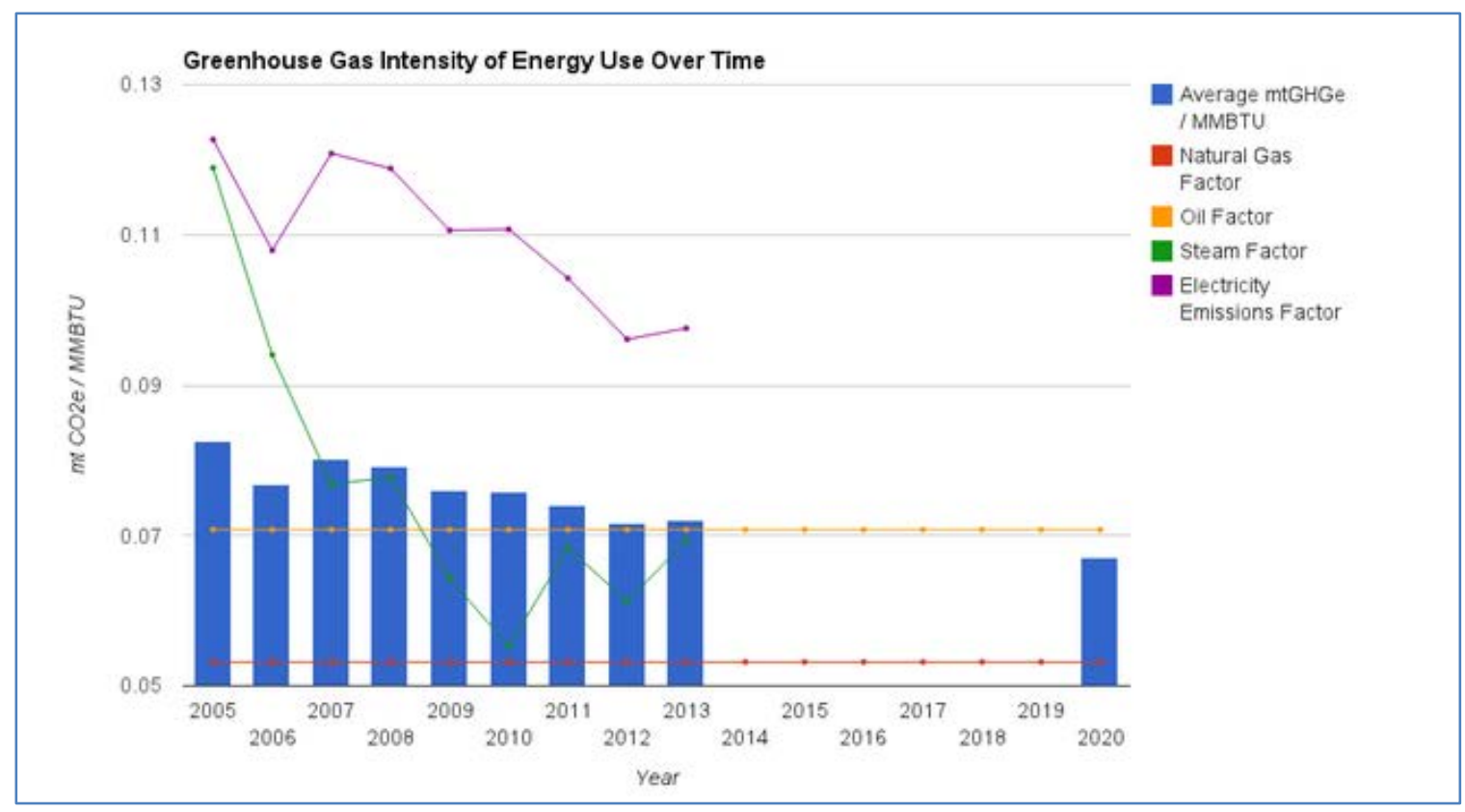

Figure 11. One of many graphs displayed on Boston's interactive "Greenovate Boston" performance dashboard ${ }^{20}$

\begin{tabular}{|c|c|c|c|c|c|c|c|}
\hline 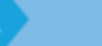 & RESOURCE CONSERVATION & & & $\mathscr{g}$ & $y$ & & है \\
\hline RC1 | & Reduce Baltimore's energy use by $15 \%$ by 2015 & & & w & & & \\
\hline$A$ & $\begin{array}{l}\text { Require aggressive energy efficiency standards as part of the Baltimore } \\
\text { Green Building standards }\end{array}$ & $\mathrm{O}$ & 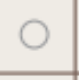 & $\mathrm{O}$ & 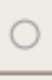 & $\bigcirc$ & $\checkmark$ \\
\hline B & Improve the energy efficiency of existing homes and buildings & $\mathrm{O}$ & O & $\bigcirc$ & $\bigcirc$ & $\bigcirc$ & $\mathscr{N}$ \\
\hline c & Increase renewable energy generation in Baltimore City & $\mathrm{O}$ & O & O & $\bigcirc$ & O & $\mathscr{Q}$ \\
\hline$D$ & Mandate efficiency upgrades to homes at point of sale & 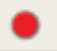 & $\bigcirc$ & O & $\mathrm{O}$ & O & $\mathscr{N}$ \\
\hline E & $\begin{array}{l}\text { Increase energy conservation by residents, City government, businesses, } \\
\text { and institutions }\end{array}$ & 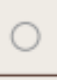 & O & O & ) & $\mathrm{O}$ & $\mathscr{N}$ \\
\hline$F$ & $\begin{array}{l}\text { Dedicate resources to assist Baltimore in leveraging state and federal funds } \\
\text { for energy efficiency }\end{array}$ & 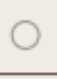 & $\mathrm{O}$ & O & $\checkmark$ & O & $\mathscr{N}$ \\
\hline G & Investigate a "Lights Out" policy for appropriate areas of Baltimore City & O & O & $\bigcirc$ & O & O & $\mathscr{N}$ \\
\hline
\end{tabular}

Figure 12. Baltimore tracks the implementation stage of different actions by goal and category in its sustainability plan annual reports. ${ }^{21}$

Collecting energy-related data and tracking metrics, both within municipal governments and community-wide, still presents an enormous challenge for cities. Numerous city staff interviewees cited barriers such as antiquated data collection software and management systems (Gill 2015) and a lack of investment in new systems (Natarajan 2015). Data collection and monitoring require significant time and staff capacity that cities must balance with the time and

${ }^{20}$ Source: Greenovate Boston (2015)

${ }^{21}$ Source: Baltimore Sustainability Plan Annual Report (2013) 
staff needs for actual program implementation (Gill 2015; Williams 2015). Internal and external stakeholder coordination and relationships also affect a city's ability to collect energy-related data and measure progress. Some cities (e.g., Minneapolis, Seattle, and Fort Collins) described successful models for delegating and coordinating data collection responsibilities across city departments; others are still in the process of obtaining buy-in from city departments and establishing effective protocols (Porteshawver 2015).

Energy-related metrics and indicators are often developed around areas where data are most available, even though staff admit better or different data would allow them to answer particular questions more effectively (Mallory and Morgenstern 2015). Over time, cities consistently track certain energy-related metrics, but others come and go from annual reports. In addition to funding, staff capacity, and technology challenges involved in data collection that may produce inconsistent metric documentation, the nature of city metrics/indicators changes as constituent and leadership priorities shift or as new or unexpected challenges arise (Prest 2015). Cities overwhelmingly acknowledge the value of frequent data collection and reporting, even if they cite barriers and shortcomings to doing so.

Perception of data and metrics, both from leadership and constituents, determines the type and extent of data collection and reporting. Though data can make a difference in convincing reluctant leadership to adopt certain policies and actions, if leaders support an idea, they do not necessarily solicit data to support it (Williams 2015). And finally, some cities choose to focus on metrics that the public can understand and support, rather than those perceived to be more esoteric (Gill 2015).

The challenge of data collection and metrics reporting in certain sectors is particularly formidable. Even as many cities successfully track municipal energy data using Portfolio Manager or other internal database systems (Smith and Phelan 2015), they still face barriers accessing community-wide energy data from utilities (Ervin 2015; Abbott 2015; Dillard 2015). If utility data are available, the precision and frequency of the data may not correspond to other types of data the city collects (Smith and Phelan 2015). The often regional nature of transportation districts and systems can pose additional challenges for cities trying to track transportation metrics exclusively within their jurisdictional boundaries (Prest 2015). Transportation data is often modeled at a regional level, the scale of which does not capture the sensitivities of local transportation interventions (Mallory and Morgenstern 2015; Smith and Phelan 2015). Some methods for tracking transportation data, such as bicycle counts, are particularly expensive for cities to do regularly; this is one factor that contributes to the infrequency of reporting related metrics (Prest 2015).

Despite these challenges, some city staff report that their cities have a history of making datadriven decisions (Prest 2015; Mallory and Morgenstern 2015; Firestone 2015; Smith and Phelan 2015), use data to solicit targeted community input (Smith and Phelan 2015), and are increasingly emphasizing open data and transparency (Ervin 2015; Natarajan 2015; Firestone 2015) — values that trickle down into the energy and climate domain. Communities that do not comprehensively document metrics to make data-driven energy decisions (for various reasons) still engage in new energy and climate city efforts because of public support. For example, although Columbia has few metrics in place, the city was able to pass a unique city-level 
renewable portfolio standard by voter referendum (Buffaloe 2015). Even in such cases, cities acknowledge the value of data collection.

\subsection{Relationship between City Goals, Actions, and Metrics: Why the Gaps?}

This analysis approaches city energy decision making with a specific framework to understand how city goals, actions, and metrics are connected. The relationships between these are often ambiguous, nonlinear, or absent from the way cities plan and make energy decisions. Interviews with city staff provide far more insight than plans themselves into how goals, actions, and metrics fit into energy decision making.

One way to explore the relationship between city energy goals and actions is to examine how CAPs, sustainability plans, and energy plans translate into specific actions. Cities report that GHG inventories guide energy-related decision making to varying degrees. Likewise, the aspirational goals, strategies, and actions outlined in CAPs and sustainability plans impact onthe-ground energy decision making in indirect and unquantifiable ways. Factors that influence whether and how plans become reality include staff capacity, financial resources, stringency, and natural resources. Cities respond that sufficient city staffing and funding to implement energy, climate, and sustainability plans are critical for turning words into action (Porteshawver 2015; Dillard 2015), while inadequate and sporadic funding creates a barrier to achieving energyrelated goals (Dillard 2015). When funding for metric tracking and reporting software such as ICLEI's CACP software dries up, as happened to one city in this analysis, cities may struggle to collect and interpret energy and GHG emission data - a likely contributor to the uneven and incomplete way some cities have tracked energy-related metrics.

Energy programs and policies also need teeth. Within some city departments, energy-related measures are not mandated, so sustainability staff must rely on voluntary adherence to sustainability programs and goals (Woodman 2015; Dillard 2015). Interviewees resoundingly acknowledged the critical role supportive leadership plays in empowering city staff to successfully implement energy and climate programs. Often, cities that demonstrate excellence in energy decision making specifically attribute much of their success to mayors and city councils who champion energy and sustainability issues. Formalizing and institutionalizing energy and climate commitments and policies is an important strategy to support continued efforts, because changes in city leadership can have the reverse effect.

In some cases, such as in Benicia, the mere existence of a CAP or sustainability plan creates the impetus for action that would not have occurred otherwise (Porteshawver 2015). Benicia's experience speaks to the usefulness of creating a CAP or sustainability plan. These plans also help cities prioritize goals and actions - often based on GHG emissions abatement potentialand identify metrics they will use to track progress. Nonetheless, some literature indicates that formalizing energy-related activities into CAPs is not as important to actual emission reductions as the underlying constituent support behind city activities (Millard-Ball 2012), a sentiment echoed in interviews with city staff.

Exceptions such as Columbia, which has no formal plan, demonstrate an alternative approach. Instead of a formal CAP or sustainability plan, Columbia reports on the status of 12 "action items" outlined in the Mayor's Climate Protection Agreement (City of Columbia Mayors 
Climate Protection Agreement Progress Report 2012). The high-level report is in narrative form, and no formal energy-related metrics are tracked. Yet, the city is taking a variety of energyrelated actions driven by constituent interest and collaboration with its municipal water and electric utility and the University of Missouri. Whether formalizing these efforts into a strategic plan would influence energy and GHG emission reductions remains to be seen.

Millard-Ball would argue that Columbia's constituent support for energy and climate initiatives alone contributes more to actual GHG emission reductions than the creation of a CAP (MillardBall 2012). As Wheeler (2008) points out, while plans are "neither necessary nor sufficient for action," "the presence of plans indicates systematic attention to the issue and plans can potentially establish an ongoing framework for action in which needs are analyzed, options are developed, the public is involved, and progress is evaluated" (Wheeler 2008, p. 483). Anecdotal evidence from city interviews suggests that there is value in "top down" planning as well as "bottom up" constituent interest in and support of energy and climate issues. Clearly, cities are still implementing energy actions, even as they undergo updates to their CAPs and sustainability plans. Plan updates, however, allow cities to reevaluate current efforts and streamline future actions (Mallory and Morgenstern 2015). 


\section{Conclusion}

City energy decision making is dynamic. At its best, goals and actions create a clear path forward, energy considerations are integrated into other areas of city planning and decision making, and cities measure the impact of programs and progress toward goals and use this information to reevaluate and improve upon strategies going forward.

In practice, however, most cities do not undertake quantitative analysis of the GHG abatement potential of each action within their energy and climate action plans. As a result, cities are less able to prioritize actions and have confidence that their cumulative impact achieves established goals.

Nonetheless, cities with energy-related plans are discussing, engaging in, and leading clean energy transformation in the United States. While actions tend to focus on the sectors within jurisdictional control (e.g., Transportation and Land Use and Buildings and Efficiency), some have not shied away from trying to impact market forces (e.g., clean energy jobs) and state and regional policymaking (e.g., electricity infrastructure).

As cities make energy decisions going forward, they should keep in mind some key insights gleaned from the experiences of cities in this analysis:

- A focus on energy savings and efficiency may facilitate progress in communities that are reluctant to directly address GHG emissions and climate change. Even if a community has committed to reducing GHG emissions at some point, changes in leadership and constituent interest over time can make an emphasis on GHG emission reductions less resonant in some communities. Energy is a key component of resiliency and adaptation initiatives - which are becoming increasingly popular - and can bolster related sustainability efforts.

- Opportunities will always arise for energy actions that fall outside plans, but creating a CAP, sustainability plan, or energy plan is still a useful exercise for formalizing ways to reach goals, prioritize actions, determine metrics to measure progress, receive community stakeholder input, and even assign responsibilities to certain city departments. Ultimately, constituent support is crucial; this can be cultivated through the CAP process, but can also be accomplished by alternative means.

- Cities throughout the United States face similar circumstances (e.g., budget shortfalls, staff capacity limitations, and political leadership shifts) that threaten to stall the implementation and measurement of energy actions. There are ways, however, to improve energy decision making despite these challenges. Developing or refining data collection protocols, collaborating with community stakeholders, empowering city departments to "own" energy initiatives, joining energy challenges and competitions, and fostering relationships with utilities and public utility commissions are examples of effective strategies, according to sampled cities, for advancing city energy-related goals. 


\section{Next Steps}

CAP, sustainability, and energy plan standardization enables comparison among cities and investigation into the national impacts of city energy and climate efforts. However, variability of scope and specificity of CAPs, combined with incomplete information and subjectivity across jurisdictions, inhibits the ability to maximize understanding of energy and climate program impacts. Although there is not a perfect correlation between city actions outlined in energy plans, CAPs, and action taken on the ground, these plans still provide a useful guide for understanding where city priorities lie or a "best-case scenario." Several strategies and resources could aid cities in their planning and implementation of energy-related goals and actions:

- Standardized measurement. The cities sampled in this study vary in the sophistication of their GHG inventories, the data available to them, and the methodologies used to measure progress. This variation makes it challenging to determine if cities are meeting their overarching GHG emission reduction goals and to compare progress among cities.

Some cities ceased conducting inventories because of the immense time and staff commitment required, the cessation of city funds required for annual use of GHG emission inventory software (e.g., ICLEI's CACP software), or the lack of data availability and credibility. Other cities expressed general confusion about which method they should adopt for reporting GHG emissions. For these reasons, providing cities with a standardized profile of their energy use that allows comparison to other cities would give cities an inexpensive way to understand their energy use in general and support action prioritization in the absence of an inventory or regular inventory updates. It would also provide the foundation for analytical work investigating city types and their energy and emission profiles.

Cities sampled in this analysis also vary in how they measure and map energy-related actions and goals. Some cities systematically connect actions to goals and GHG reduction potential, but in many city plans, the distinction between actions, strategies, and goals is ambiguous. Moreover, most U.S. jurisdictions have not completed any form of CAP, energy plan, or sustainability plan. Besides not having the right resources to measure progress, cities often do not know what to measure. These cities in particular would benefit from a standardized methodology and metrics for mapping their energy-related actions to goals.

- Energy and GHG impact. Cities need to understand the estimated energy reduction and GHG abatement potential of actions to better prioritize and allocate resources accordingly. Otherwise, they risk focusing on actions that appear to reduce GHG emissions or are merely politically expedient, instead of the most impactful actions. For example, city staff from Seattle expressed the need for better research about the effectiveness of specific programs or policies. While Seattle tracks the large-scale, aggregate GHG changes year-to-year, the city does not empirically verify specific program impacts. Without information about specific program impact, Seattle staff do not know whether implementing specific programs (e.g., mandatory energy audits - a popular program in other large cities) will make a difference on overall GHG emissions (Mallory and Morgenstern 2015). 
Similarly, Anand Natarajan from the Cleveland Office of Sustainability asked, "What are key actions Cleveland should be doing that would drive more momentum?" (Natarajan 2015) Though helpful for cities across the spectrum, this information is most useful for cities who have not embarked on a comprehensive plan for identifying or accomplishing energy-related city goals and those who lack the financial and human resources to create accurate estimates of action impacts. Consolidating city energy best practices and case study literature with energy and GHG impacts, into a database or similar structure would be a useful way to organize this currently scattered information.

Standardized estimates of the energy and GHG emissions reduction potential of city actions, policies, and programs combined with the results of this analysis - an understanding of which actions and goals cities are emphasizing as future prioritiesprovide the foundation for assessing the potential national impact of city energy and climate efforts in the aggregate. Even if not every action is achievable in a future policy environment, CAPs, sustainability plans, and energy plans guide the direction cities aspire to move in or feel capable of moving in. With a better understanding of what they can do collectively, cities may feel even more empowered to renew their leadership in the transition to a clean energy future.

- City typologies. Generally speaking, several factors impact a city's (from a global perspective) energy use. These include geography (i.e., climate and natural resource endowment), socioeconomics, a city's role in local, national, and international economies, the built environment, and types of energy systems and markets in which cities are embedded (Bai et al. 2013). However, research about the drivers of urban energy use is still in a nascent stage. Future research could also explore energy-related actions and goals by city characteristics, including socioeconomics, geography, or the built environment, to understand whether city type influences the types of energy-related goals and actions cities pursue and the energy and GHG emission impacts of adopted actions..

- Cost-effectiveness. Cities would also benefit from a better understanding of the costeffectiveness of actions, from the city, consumer, and societal perspective, to aid action prioritization. In interviews with city staff responsible for energy-related planning and programs, cost frequently came up as an important consideration in city action prioritization and implementation. Providing cost-effectiveness estimates of specific actions or groups of actions enables local decision makers to implement fiscally sound energy-related programming that will move the needle on meeting energy and GHG emission reduction targets. 


\section{References}

2011 Status Report: Fort Collins Climate Action Plan (2011). Fort Collins, CO: City of Fort Collins. Accessed March 17, 2015: http:/www.fcgov.com/climateprotection/pdf/2011-capstatus-report.pdf?1347480001.

Abbott, M. (March 12, 2015). Phone interview. Environmental Sustainability Team, Park City, UT.

ACEEE (2013). The 2014 City Energy Efficiency Scorecard. Washington, D.C.: American Council for an Energy-Efficient Economy.

Anguelovski, I.; Carmin, J. (2011). "Something Borrowed, Everything New: Innovation and Institutionalization In Urban Climate Governance." Current Opinion in Environmental Sustainability (3:3), pp. 169-175.

Bai, X; Dhakal, S.; Steinberger, J.; Weitz, H. (2013). "Drivers of Urban Energy Use and Main Policy Levers." Grubler, A., Fisk D., Ed. Energizing Sustainable Cities. Routledge Taylor \& Francis Group, London \& New York.

Baltimore Climate Action Plan (2013). Baltimore, MD: City of Baltimore. Accessed March 17, 2015:

http://www.baltimoresustainability.org/sites/baltimoresustainability.org/files/BaltimoreCAP_FIN AL_130415.pdf.

Bassett, E.; Shandas, V. (2010). "Innovation and Climate Action Planning: Perspectives From Municipal Plans." Journal of the American Planning Association, (76:4), pp. 435-450.

Bauer, J. (2014.) 'Urban Sustainability Directors' Network (USDN)." Presented at the National Renewable Energy Laboratory’s Cities Leading Through Energy Analysis and Planning workshop.

Betsill, M.M. (2001). "Mitigating Climate Change in US Cities: Opportunities and Obstacles." Local Environment, (6:4), pp. 393-406.

Betsill, M.M.; Bulkeley, H. (2006). "Cities and the Multilevel Governance Of Global Climate Change." Global Governance: A Review of Multilateralism and International Organizations (12:2), pp. 141-159.

Blackmon. A. (March 27, 2015.) Email to Alexandra Aznar. National Renewable Energy Laboratory. Greenovate Boston, Mayor's Office. Boston, MA.

Buffaloe, B. (March 20, 2015). Phone interview. Office of Sustainability, Columbia, MO.

Bulkeley, H.; Betsill, M. (2005). "Rethinking Sustainable Cities: Multilevel Governance and The 'Urban’ Politics Of Climate Change.” Environmental Politics (14:1), pp. 42-63. 
Busche, S. 2010. "Clean Energy Policy Analyses: Analysis of the Status and Impact of Clean Energy Policies at the Local Level." National Renewable Energy Laboratory. Accessed May 11, 2015. http://www.nrel.gov/docs/fy11osti/49720.pdf.

California Air Resources Board, California Climate Action Registry, ICLEI-Local Governments for Sustainability, and The Climate Registry (May 2010). Local Government Operations Protocol for the Quantification and Reporting of Greenhouse Gas Emissions Inventories, Version 1.1. Accessed March 26, 2015: http://www.icleiusa.org/action-center/tools/localgovernment-operations-protocol.

Charleston Green Plan: A Roadmap to Sustainability (2010). Charleston, SC: City Council Green Committee. Accessed March 17, 2015: http://www.charlestongreencommittee.com/charlestongreenplan2010.pdf.

Charleston Green Plan Inventory \& Metrics (2009). Charleston, SC: City of Charleston Green Committee. Accessed March 17, 2015: http://sccharleston.civicplus.com/documentcenter/view/1462.

"Charlottesville Emissions Reports" (2008, 2012). City of Charlottesville. Accessed March 17, 2015: http://www.charlottesville.org/Index.aspx?page=3418.

Chicago Climate Action Plan (2008). Chicago, IL: City of Chicago. Accessed February 5, 2015:http://www.chicagoclimateaction.org/filebin/pdf/finalreport/CCAPREPORTFINALv2.pdf.

Chicago's Greenhouse Gas Emissions: An Inventory, Forecast and Mitigation Analysis for Chicago and the Metropolitan Region (2008). Chicago, IL: The Center for Neighborhood Technology. Accessed March 17, 2015: http://www.chicagoclimateaction.org/filebin/pdf/CNTClimateResearchSummary91708.pdf.

City of Baltimore Greenhouse Gas Emissions Analysis_(2009). Baltimore, MD: City of Baltimore. Accessed March 17, 2015:

http:/www.baltimoresustainability.org/sites/baltimoresustainability.org/files/Full\%20GHG\%20I nventory\%20Report $\% 202007 \% 2010.7 .09$.pdf.

City of Columbia, Missouri Greenhouse Gas Inventory: Update and Emission Reduction Recommendations (2010). Columbia, MO: City of Columbia. Prepared by James Mitchell. Accessed March 25, 2015:

http:/www.gocolumbiamo.com/Sustainability/documents/MicrosoftWordColumbiaGHG2012FINALREPORT.pdf.

City of Dallas Greenhouse Gas Emissions Inventory: 2012 (2012). Dallas, TX: City of Dallas. Accessed March 17, 2015: http://greendallas.net/wpcontent/uploads/2013/04/GHG_EmissionsReport_Final2012.pdf.

City of Flagstaff Community Greenhouse Gas Emissions Report (2009, 2010). Flagstaff, AZ: City of Flagstaff. Accessed March 17, 2015: http://www.flagstaff.az.gov/DocumentCenter/Home/View/14150. 
City of New York, Inventory of New York City Greenhouse Gas Emissions (2013) Mayor's Office of Long-Term Planning and Sustainability, New York, 2013.

Cleveland Climate Action Plan: Building Thriving and Healthy Neighborhoods (2013).

Cleveland, OH: Sustainable Cleveland 2019. Accessed February 5,

2015:http://www.sustainablecleveland.org/wp-content/uploads/2013/10/Cleveland-Climate-

Action-Plan-Final2013-web.pdf.

Climate Action Plan 2009 (2009). Mission, KS: City of Mission. Accessed March 17, 2015:

http://www.missionks.org/docview.aspx?docid=15977.

Climate Action Plan: Introduction (2009). Benicia, CA: City of Benicia. Accessed March 17, 2015: http://www.sustainablebenicia.org/files/cap/Introduction.pdf.

Climate LA. (2007). Environment LA. Accessed March 17, 2015:

http://environmentla.org/ead_GreenLAClimateLA.htm.

Community Footprint : Community Carbon Footprint (2015.) Park City, UT. Accessed March 25, 2015. http://www.parkcitygreen.org/Community/Community-Footprint/Community-CarbonFootprint.aspx.

Coenen, F.; Menkveld, M. (2002). "The Role of Local Authorities in a Transition Towards a Carbon-Neutral Society.” Kok, M.T.J., Vermeulen, W.J., Faaij, A.P.C., \& de Jager, D., eds. Global Warming and Social Innovation: The Challenge of a Climate Neutral Society, London: Earthscan Publications; pp. 107-125.

Corfee-Morlot, J.; Kamal-Chaoui, L.; Donovan, M.G.; Cochran, I.; Robert, A.; Teasdale, P.J. (2009). "Cities, Climate Change, and Multilevel Governance." OECD Environment working paper.

Dillard, J. (March 12, 2015). Phone interview. Public Works Department, Dallas, TX.

DOE (2013). Guide to Community Energy Strategic Planning. Washington, D.C.: U.S.

Department of Energy. Accessed March 26, 2015:

http://energy.gov/sites/prod/files/2014/05/f15/cesp_guide.pdf.

EPA (2011-2014). "Local Government Climate and Energy Strategy Series.” Washington, D.C.: U.S. Environmental Protection Agency. Accessed March 26, 2015:

http://www.epa.gov/statelocalclimate/resources/strategy-guides.html.

Erikson, P.; Lazarus, M.; Chandler, C.; Schultz, S. (2013). “Technologies, Policies, and Measure For GHG Abatement at the Urban Scale." Greenhouse Gas Measurement and Management, (3:1-2), pp. 37-54.

Ervin, G. (March 9, 2015). Phone interview. Office of Mayor William Peduto, Pittsburgh, PA.

Firestone, H. (March 24, 2015). Phone interview. Office of Mayor Eric Garcetti, Los Angeles, CA. 
City of Mission GHG Emissions Inventory (2008). Mission, KS. Prepared for City of Mission by Black \& Veatch. Accessed March 25, 2015:

http://www.missionks.org/docview.aspx?docid=15978.

Gill, E. (March 5, 2015). Phone interview. Office of Sustainability, Knoxville, TN.

Global Commission on the Economy and Climate (2014). Better Growth, Better Climate: The New Climate Economy Report. Accessed March 26, 2015: http://newclimateeconomy.report/.

Greenovate Boston (2015). "Measuring Progress.” Accessed March 25, 2015:

http://plan.greenovateboston.org/.

ICLEI-Local Governments for Sustainability USA (2012). U.S. Community Protocol for Accounting and Reporting of GHG Emissions. Version 1.1. Revised July 2013. Accessed May 21, 2015: http://www.icleiusa.org/tools/ghg-protocol/community-protocol.

International City/County Management Association (ICMA). (2010). "ICMA 2010 Sustainability Survey Results." Accessed February 9, 2015:

http://icma.org/en/icma/knowledge network/documents/kn/Document/301646/ICMA_2010_Sus tainability_Survey_Results.

Joseph, A. (April 2, 2015). Phone interview. Office of the Mayor, Chicago, IL.

Jossi, F. 2014. "Minneapolis Utility Fight Ends with Unique Clean Energy Deal.” Midwest Energy News. Accessed May 11, 2015:

http://www.midwestenergynews.com/2014/10/17/minneapolis-utility-fight-ends-with-uniqueclean-energy-deal/.

Keirstead, J.; Shah, N. (2013). "Urban Energy Systems Planning, Design, and Implementation.” Grubler, A., Fisk D. Ed. Energizing Sustainable Cities. Routledge Taylor \& Francis Group, London \& New York.

Knoxville Energy Inventory: Government and Community Analysis and Strategic Plans (undated). Knoxville, TN: City of Knoxville Policy and Communications Department. Accessed March 17, 2015: http://www.cityofknoxville.org/sustainability/Knoxville_Energy_Inventory.pdf.

Kousky, C.; Schneider, S.H. (2003). "Global Climate Policy: Will Cities Lead the Way?” Climate Policy, (3:4), pp. 359-372.

Krause, R. (2010). "Policy Innovation, Intergovernmental Relations, and the Adoption of Climate Protection Initiatives by U.S. Cities.” Journal of Urban Affairs (33:1), pp. 45-60.

Lindseth, G. (2004). "The Cities for Climate Protection Campaign (CCPC) and the Framing of Local Climate Policy.” Local Environment (9:4), pp. 325-336.

Mackres, E. and Kazerooni, B. (2012). "Local Energy Planning in Practice: A Review of Recent Experiences." American Council for an Energy-Efficient Economy (ACEEE). Accessed March 26, 2015: http://aceee.org/research-report/e123. 
Mackres, E.; Hayes, S. (2012). "Keeping It in the Community: Sustainable Funding for Local Energy Efficiency Initiatives." American Council for an Energy-Efficient Economy (ACEEE). Accessed March 26, 2015: http://aceee.org/research-report/e124.

Mallory, S.; Morgenstern, T. (March 20, 2015). Phone interview. Seattle Office of Sustainability and Environment, Seattle, WA.

Mayors Climate Protection Agreement Progress Report. 2012. Columbia, MO: City of Columbia. Accessed March 17, 2015:

http://www.gocolumbiamo.com/Sustainability/documents/ClimateProtectionAgreementReport.p df.

Millard-Ball, A. (2012). "Do City Climate Plans Reduce Emissions?” Journal of Urban Economics (71), pp. 289-311).

Minneapolis Climate Action Plan: A Roadmap To Reducing Citywide Greenhouse Gas Emissions (2013). Minneapolis, MN: Minneapolis City Coordinator Sustainability Office. Accessed March 17, 2015:

http://www.ci.minneapolis.mn.us/www/groups/public/@,citycoordinator/documents/webcontent/ wcms 1p-113598.pdf.

Natarajan, A. (March 5, 2015). Phone interview. Mayor's Office of Sustainability, Cleveland, $\mathrm{OH}$.

OpenEI (2015). International Council for Local Environmental Initiatives (ICLEI) Clean Air and Climate Protection Software Tools. Accessed March 26, 2015:

http://en.openei.org/wiki/International_Council_for_Local_Environmental_Initiatives_(ICLEI)_ Clean_Air_and_Climate_Protection_Software_Tools.

Park City SOS Action Plan (2010). Park City, UT: Park City Municipal and Brendle Group. Accessed March 17, 2015: http://www.parkcitygreen.org/Community/CommunityFootprint/Documents/Park-City-SOS-Action-Plan_4-28-2010.aspx.

Peterson, D., Matthews, E. and Weingarden, M. 2011. "Local Energy Plans in Practice: Case Studies of Austin and Denver." National Renewable Energy Laboratory, Austin Climate Protection Program, and Greenprint Denver. Accessed May 11, 2015:

http://www.nrel.gov/docs/fy11osti/50498.pdf.

Porteshawver, A. (March 16, 2015). Phone interview. Consulting Climate Action Plan Coordinator. PMC, a Michael Baker International Company. California.

Portney, K.E. (2002). "Taking Sustainable Cities Seriously: A Comparative Analysis of TwentyFour US Cities.” Local Environment (7:4), pp. 363-380.

Portney, K. (2005). "Civic Engagement and Sustainable Cities in the United States." Public Administration Review (65:5), pp. 579-591. 
Portney, K.E; Berry, J.M. (2010). "Participation and the Pursuit of Sustainability in US Cities." Urban Affairs Review (46:1), pp. 119-139.

Prest, G. (March 19, 2015). Phone interview. Minneapolis Sustainability Office, Minneapolis, MN.

Randel, E. (March 17, 2015). Phone interview. Administration Department, Mission, KS.

Riddervold, K. (March 27, 2015.) Phone interview. Department of Public Works. Environmental Sustainability Division. Charlottesville, VA

Seattle Climate Action Plan (2013). Seattle, WA: Seattle Office of Sustainability \& Environment. Accessed March 17, 2015:

http://www.seattle.gov/Documents/Departments/OSE/2013_CAP_20130612.pdf.

Seattle Community Greenhouse Gas Emissions Inventory (2012)._Seattle, WA: Seattle Office of Sustainability \& Environment. Prepared by Stockholm Environment Institute. Accessed March 17, 2015:

http:/www.seattle.gov/Documents/Departments/OSE/2012\%20GHG\%20inventory\%20report fi nal.pdf.

Seto, K.C.; Dhakal, S. (2014). "Human Settlements, Infrastructure, and Spatial Planning. In Climate Change 2014: Mitigation of Climate Change. Contribution of Working Group III to the Fifth Assessment Report of the Intergovernmental Panel on Climate Change. O. Edenhofer, R. Pichs-Madruga, Y. Sokona, E. Farahani, S. Kadner, et al, Eds. Cambridge University Press, Cambridge, UK, and New York.

Smith, L.; Phelan, J. (March 27, 2015.) Phone interview. Environmental Service Department. Fort Collins Utilities. Fort Collins, CO.

Sparking Boston's Climate Revolution (2010). Boston, MA: City of Boston Climate Action Leadership Committee and Community Advisory Committee. Accessed March 17, 2015: http://www.cityofboston.gov/Images_Documents/BCA_full_rprt_r5 tcm3-19558.pdf.

STAR Communities. STAR Community Rating System, Version 1.1 (2014). Accessed March 26, 2015: http://www.starcommunities.org/rating-system/download/.

Stone, B.; Vargo, J.; Habeeb, D. (2012). "Managing Climate Change in Cities: Will Climate Action Plans Work?" Landscape and Urban Planning (107:3), pp. 263-271.

Stout, S. 2014. "Jurisdictional Authority: Who has the (solar) power?" State and Technical Assistance Team Blog. National Renewable Energy Laboratory. Accessed May 11, 2015: https://www.nrel.gov/tech deployment/state local governments/blog/jurisdictional-authority.

Svara, J.; Read, A.; Moulder, E. (2011). "Breaking New Ground: Promoting Environmental and Energy Programs in Local Government." IBM Center for the Business of Government. Conserving Energy and the Environment Series. 
Svara, J.; Watt, T.; Jang, H. (2013). "How Are U.S. Cities Doing Sustainability? Who Is Getting on the Sustainability Train, and Why?" Cityscape: A Journal of Policy Development and Research (15:1), pp. 9-34.

Tang, Z.; Brody, S. D.; Quinn, C.; Chang, L.; Wei, T. (2010). "Moving From Agenda to Action: Evaluating Local Climate Change Action Plans.” Journal of Environmental Planning and Management (53:1), pp. 41-62.

U.S. Census Bureau. (2015). “Geographic Terms and Concepts-Place.” Geography. Accessed December 12, 2014: https://www.census.gov/geo/reference/gtc/gtc_place.html.

U.S. Census Bureau (2015). "Population of Interest-Municipalities and Townships.” Lists \& Structures of Government. Accessed December 12, 2015 : https://www.census.gov/govs/go/municipal_township_govs.html.

The United States Conference of Mayors (2006). The United States Conference of Mayors: Energy and the Environment Best Practices Report. Second National Summit on Energy \& the Environment. Accessed March 26, 2015:

http://www.usmayors.org/climateprotection/AtlantaEESummitCDROMVersion.pdf

"U.S. Conference of Mayors Climate Protection Agreement" (2008). U.S. Conference of Mayors. Accessed March 31, 2015: http://www.usmayors.org/climateprotection/agreement.htm.

Wheeler, S.M. (2008). "State and Municipal Climate Change Plans: The First

Generation." Journal of the American Planning Association (74:4), pp. 481-496.

Williams, C. (March 23, 2015). Phone interview. Planning, Preservation and Sustainability Department, Charleston, SC.

Woodman, N. (March 6, 2015). Phone interview. Flagstaff Sustainability Program, Flagstaff, AZ.

Zahran, S.; Grover, H.; Brody, S. D.; Vedlitz, A. (2008). "Risk, Stress, and Capacity Explaining Metropolitan Commitment to Climate Protection." Urban Affairs Review (43:4), pp. 447-474. 


\section{Bibliography}

2008 Fort Collins Climate Action Plan: Interim Strategic Plan Towards 2020 Goal. (2008). Fort

Collins, CO: City of Fort Collins. Accessed March 17, 2015:

http://www.fcgov.com/climateprotection/pdf/climate action_plan.pdf.

2009 Annual Sustainability Report. (2009). Baltimore, MD: Baltimore Office of Sustainability. Accessed March 17, 2015:

http://www.baltimoresustainability.org/sites/baltimoresustainability.org/files/Annual\%20Report \%20Final\%20\%28online\%20download\%20version\%29_1.pdf.

2010 Annual Progress Report. (2010). Dallas, TX: City of Dallas. Accessed March 17, 2015: http://dallascityhall.com/departments/OEQ/DCH\%20Documents/annualreport2010.pdf.

2010 Annual Sustainability Report. (2010). Baltimore, MD: Baltimore Office of Sustainability. Accessed March 17, 2015:

http://www.baltimoresustainability.org/sites/baltimoresustainability.org/files/AnnualReport.2010 .ForWeb 0.pdf.

2010 Municipal Operations Sustainability Annual Report. (2010). Fort Collins, CO: City of Fort Collins. Accessed March 17, 2015: http://www.fcgov.com/sustainability/annualreports/2010report.pdf.

2011 Annual Progress Report. (2011). Dallas, TX: City of Dallas. Accessed March 17, 2015: http://dallascityhall.com/departments/OEQ/DCH\%20Documents/annualreport2011.pdf.

2011 Annual Sustainability Report. (2011). Baltimore, MD: Baltimore Office of Sustainability. Accessed March 17, 2015:

http://www.baltimoresustainability.org/sites/baltimoresustainability.org/files/AnnualReport2011 web $0 . p d f$.

2012 Annual Progress Report. (2012). Dallas, TX: City of Dallas. Accessed March 17, 2015: http://dallascityhall.com/departments/OEQ/DCH\%20Documents/annualreport2012.pdf.

2012 Annual Sustainability Report. (2012). Baltimore, MD: Baltimore Office of Sustainability. Accessed March 17, 2015:

http://www.baltimoresustainability.org/sites/baltimoresustainability.org/files/BaltimoreOfficeofS ustainability_2012AnnualReport_singlepages.pdf.

2013 Annual Sustainability Report. (2013). Baltimore, MD: Baltimore Office of Sustainability. Accessed March 17, 2015:

http://www.baltimoresustainability.org/sites/baltimoresustainability.org/files/AR2013 FINAL w eb small.pdf.

2015 Sustainable Chicago Action Agenda. (2015). Chicago, IL: City of Chicago. Accessed March 17, 2015:

http://www.cityofchicago.org/content/dam/city/progs/env/SustainableChicago2015.pdf. 
2015 Sustainable Chicago Action Agenda: Year One Report. (2015). Chicago, IL: City of Chicago. Accessed March 17, 2015:

http://www.cityofchicago.org/content/dam/city/progs/env/SCYear1Report.pdf.

2015 Sustainable Chicago Action Agenda: 6 month update. (2015). Chicago, IL: City of Chicago. Accessed March 17, 2015:

http://www.cityofchicago.org/content/dam/city/progs/env/SustainableChicago6MonthProgress.p df.

A Climate of Progress: City of Boston Climate Action Plan Update 2011. (2011). Boston, MA: City of Boston. Accessed March 17, 2015: http://www.cityofboston.gov/images documents/A\%20Climate\%20of\%20Progress \%20\%20CAP\%20Update\%202011 tcm3-25020.pdf.

Boswell, Michael; Greve, Adrienne; Seale, Tammy (2010). "An assessment of the link between greenhouse gas emissions inventories and climate action plans." Journal of the American Planning Association, (76:4), pp. 451-462 \.

Chicago 2010 Regional Greenhouse Gas Emissions Inventory. (2010). Chicago, IL: Chicago Metropolitan Agency for Planning. Accessed March 17, 2015:

http://www.cmap.illinois.gov/documents/10180/27573/Chicago_2010_Regional_Greenhouse_G as_Emissions_Inventory 05-22-12.pdf/adf2a647-246e-48e0-aead-2766fa3281e8.

Chicago Climate Action Plan Dashboard. (2010). Chicago, IL: City of Chicago. Accessed March 17, 2015: http://www.chicagoclimateaction.org/filebin/pdf/CCAPDashboard2010v2.pdf.

Chicago Climate Action Plan: Progress Report. (2008). Chicago, IL: City of Chicago. Accessed March 17, 2015: http://www.chicagoclimateaction.org/filebin/pdf/CCAPProgressReportv3.pdf.

"Chicago Releases New Datasets for a More Sustainable City." (2013). Chicago Digital. Accessed March 17, 2015: http://digital.cityofchicago.org/index.php/chicago-releases-newdatasets-for-a-more-sustainable-city/.

City of Dallas 2009 Annual Progress Report. (2009). Dallas, TX: City of Dallas. Accessed March 17, 2015: http://dallascityhall.com/departments/OEQ/DCH\%20Documents/annualreport2009.pdf.

City of Flagstaff Annual Report on Sustainability 2013. (2013). Flagstaff, AZ: City of Flagstaff. Accessed March 17, 2015: http://flagstaff.az.gov/DocumentCenter/View/44507.

City of Flagstaff Municipal Greenhouse Gas Emissions Report. (2011). Flagstaff, AZ: City of Flagstaff. Accessed March 17, 2015:

http://www.flagstaff.az.gov/DocumentCenter/Home/View/16008.

City of Fort Collins Action Plan for Sustainability: Policy and Recommended Strategies. (2004). Fort Collins, CO: City of Fort Collins. Accessed March 17, 2015:

http://www.fcgov.com/sustainability/pdf/sustainability-plan.pdf?1183060437. 
City of Knoxville Energy \& Sustainability Initiative: 2014 Work Plan \& Emissions Inventory Update. (2014). Knoxville, TN: City of Knoxville. Accessed March 17, 2015:

http://www.cityofknoxville.org/sustainability/2014workplan.pdf.

Climate Action Plan: Energy Production. (2009). Benicia, CA: City of Benicia. Accessed March 17, 2015: http://www.sustainablebenicia.org/files/cap/EnergyProduction.pdf.

Climate Action Plan: Transportation \& Land Use. (2009). Benicia, CA: City of Benicia. Accessed March 17, 2015:

http:/www.sustainablebenicia.org/files/cap/Transportationandlanduse.pdf.

Climate Action Plan: Buildings. (2009). Benicia, CA: City of Benicia. Accessed March 17, 2015 : http://www.sustainablebenicia.org/files/cap/Buildings.pdf.

Community Sustainability: City of Flagstaff Annual Report on Sustainability: 2009. (2009). Flagstaff, AZ: City of Flagstaff. Accessed March 17, 2015:

http://www.flagstaff.az.gov/DocumentCenter/Home/View/12014.

Community Sustainability: City of Flagstaff Annual Report on Sustainability: 2012. (2012). Flagstaff, AZ: City of Flagstaff. Accessed March 17, 2015: http://www.flagstaff.az.gov/DocumentCenter/View/41372.

“Comprehensive Plan 2013.” (2013). City of Charlottesville. Accessed March 17, 2015: http://www.charlottesville.org/index.aspx?page $=3523$.

Executive Summary: 1990 \& 2007 Carbon Inventory Baseline Assessment. (2008). Park City, UT: Park City Municipal Corporation. Accessed March 17, 2015:

http://www.parkcitygreen.org/Documents/Carbon-Footprint-Executive-Summary_FINAL.aspx.

"Green Buildings in Pittsburgh." (2015). Office of Sustainability. Accessed March 17, 2015: http:/www.pittsburghpa.gov/green/buildings.htm.

Greenovate Boston: 2014 Climate Action Plan Update. (2014). Boston, MA: City of Boston. Accessed March 17, 2015:

http://www.cityofboston.gov/eeos/pdfs/Greenovate $\% 20$ Boston $\% 202014 \% 20$ CAP\%20Update F $\underline{\text { ull.pdf. }}$

Greenhouse Gas Emissions Management Program. (2008). Flagstaff, AZ: City of Flagstaff and Trinity Consultants. Accessed March 17, 2015:

http://flagstaff.az.gov/DocumentCenter/Home/View/8630.

Knoxville's Energy \& Sustainability Work Plan. (undated). Knoxville, TN: City of Knoxville Policy and Communications Department, Energy \& Sustainability Office. Accessed March 17, 2015: http://www.cityofknoxville.org/sustainability/esworkplan.pdf.

"LADWP Current Sustainability Action Plan." (2009). Los Angeles Department of Water and Power. Accessed March 17, 2015: https://adwp.com/ladwp/faces/wcnav_externalId/a-ioccmitmnt-sustnblty? adf.ctrl- 
state $=$ vbyxp7rv $4 \&$ afrLoop $=566762959932211 \& \_$afrWindowMode $=0 \&$ afrWindowId $=4 \mathrm{tt} 5 \mathrm{kp}$ ry9 1\#\%40\%3F afrWindowId\%3D4tt5kpry9 1\%26 afrLoop\%3D566762959932211\%26 afrW indowMode\%3D0\%26 adf.ctrl-state\%3D4tt5kpry9 17.

"Los Angeles Open Data." (undated). Data L.A. Accessed March 17, 2015 : https://data.lacity.org/.

Mayors Climate Protection Agreement Progress Report. (2012). Columbia, MO: City of Columbia. Accessed March 17, 2015:

http://www.gocolumbiamo.com/Sustainability/documents/ClimateProtectionAgreementReport.p df.

Municipal Sustainability Plan. (2013). Flagstaff, AZ: City of Flagstaff. Accessed March 17, 2015: http://flagstaff.az.gov/DocumentCenter/Home/View/14041.

"Office of Environmental and Energy Services." (undated). City of Boston. Accessed March 17, 2015: http://www.cityofboston.gov/eeos/.

Executive Order of Mayor Thomas M. Menino: An Order Relative to Climate Action in Boston. (2007).Office of the Mayor. EO 617/635-4000. Boston City Hall (April 13, 2007): http://www.cityofboston.gov/images_documents/Clim_Action_Exec_Or_tcm3-3890.pdf.

One City, One Plan: Greening Hartford and Sustainable Development. (2010). Hartford, CT: City of Hartford. Accessed March 17, 2015:

http://www.hartfordinfo.org/issues/wsd/Government/gblock/OCOP9GreeningHartfordandSustainableDevelopment_Final.pdf.

Pittsburgh Climate Action Plan. (2012). Pittsburgh, PA: Pittsburgh Climate Initiative. Accessed March 17, 2015: http://pittsburghclimate.org/wp-content/uploads/2011/12/Pittsburgh-ClimateAction-Plan-Version-2-FINAL-Web.pdf.

Pittsburgh Climate Protection Initiative Greenhouse Gas Emissions Inventory. (2011). Pittsburgh, PA: City of Pittsburgh. Accessed March 17, 2015: http://pittsburghclimate.org/wpcontent/uploads/2011/12/PittsburghInventoryReport.pdf.

Pittsburgh Greenhouse Gas Emissions Inventory A 5-Year Benchmark. (2008). Pittsburgh, PA: Pittsburgh Climate Initiative. Accessed March 17, 2015: http://pittsburghclimate.org/wpcontent/uploads/2011/12/PCI-2008-GHG-Inventory.pdf.

PlaNYC: A Greener, Greater New York. (2007). New York, NY: The City of New York. Accessed March 17, 2015:

http://www.nyc.gov/html/planyc/downloads/pdf/publications/full_report_2007.pdf.

PlaNYC: Full Report 2011. (2011). New York, NY: The City of New York. Accessed March 17, 2015:

http://www.nyc.gov/html/planyc/downloads/pdf/publications/planyc 2011_planyc_full_report.p df. 
PlaNYC: Progress Report 2008. (2008). New York, NY: The City of New York. Accessed March 17, 2015:

http://www.nyc.gov/html/planyc/downloads/pdf/publications/planyc progress_report 2008.pdf.

PlaNYC: Progress Report 2009. (2009). New York, NY: The City of New York. Accessed March 17, 2015:

http://www.nyc.gov/html/planyc/downloads/pdf/publications/planyc progress_report_2009.pdf.

PlaNYC: Progress Report 2012. (2012). New York, NY: The City of New York. Accessed March 17, 2015:

http://www.nyc.gov/html/planyc/downloads/pdf/publications/planyc progress_report_2012.pdf.

PlaNYC: Progress Report 2013. (2013). New York, NY: The City of New York. Accessed March 17, 2015:

http://www.nyc.gov/html/planyc/downloads/pdf/publications/planyc progress_report_2013.pdf.

PlaNYC: Progress Report 2014. (2014). New York, NY: The City of New York. Accessed March 17, 2015:

http://www.nyc.gov/html/planyc/downloads/pdf/publications/140422_PlaNYCP-

Report_FINAL_Web.pdf.

"Sustainable Cleveland 2019 Dashboard." (undated). Sustainable Cleveland 2019. Accessed March 17, 2015: http://www.sustainablecleveland.org/about/dashboard/.

Sustainable Cleveland Report from the Community. (2014). Cleveland, OH: Cleveland Community. Accessed March 17, 2015: http://www.sustainablecleveland.org/wpcontent/uploads/2014/09/Report 9.4.pdf.

Sustainable Mission: 2015 Plan Initiatives. (2015). Mission, KS: City of Mission. Accessed March 17, 2015: http://www.missionks.org/docview.aspx?docid=17438.

"Sustainability Goals." (2015). City of Fort Collins. Accessed March 17, 2015:

http://www.fcgov.com/sustainability/goals.php.

"Sustainability Indicators: Citywide Greenhouse Gas Emissions." (undated). Official Website of the City of Minneapolis. Accessed March 17, 2015:

http://www.minneapolismn.gov/sustainability/indicators/WCMS1P-087163.

"Sustainability Indicators." (undated). Official Website of the City of Minneapolis. Accessed March 17, 2015: http://www.minneapolismn.gov/sustainability/indicators/index.htm.

Sustainability Programs \& Initiatives Plan. (2010). Mission, KS: City of Mission. Accessed March 17, 2015: http://www.missionks.org/docview.aspx?docid=15976.

Sustainability Progress Report. (2014). Dallas, TX: City of Dallas. Accessed March 17, 2015: http://greendallas.net/wp-content/uploads/Sustainability-Plan-Progress-Report-2014-FINAL.pdf. 
The Baltimore Sustainability Plan. (2009). Baltimore, MD: City of Baltimore. Accessed March 17, 2015:

http://www.baltimoresustainability.org/sites/baltimoresustainability.org/files/Baltimore\%20Susta inability\%20Plan\%20FINAL.pdf.

"The Local Climate Action Planning Process." (2011). City of Charlottesville. Accessed March 17, 2015: http://www.charlottesville.org/Index.aspx?page=3446.

Tomer, Adie; Kane, Joseph. (2014). Mapping Freight: The Highly Concentrated Nature of Goods Trade in the United States. Global Cities Initiative. Brookings Institute and JP Morgan Chase. Accessed February 1, 2015. http://www.brookings.edu/ /media/Research/Files/Reports/2014/11/freightnetworks/Srvy GCIFreightNetworks Oct24.pdf?la=en.

U.S. Census Bureau. (2015). “American Community Survey 5-Year Estimates 2009-2013:

Median Income in the Past 12 Months (In 2013 Inflation-adjusted dollars)." Accessed December 15, 2014.

http://factfinder.census.gov/faces/tableservices/jsf/pages/productview.xhtml?src=bkmk.

U.S. Census Bureau. (2015). “Land area, 2000.” County and City Data Book 2000. Accessed December 15, 2014. https://www.census.gov/statab/ccdb/cityrank.htm.

U.S. Census Bureau. (2015). "Population Estimates: Annual Estimates of the Resident Population for Incorporated Places: April 1, 2010-July 1, 2010. Accessed December 15, 2014. http://www.census.gov/popest/data/cities/totals/2013/SUB-EST2013-3.html.

U.S. Census Bureau (2015). "Population Estimates: Geographic terms and definitions." Accessed April 3, 2015.http:/www.census.gov/popest/about/geo/terms.html.

U.S. Department of Transportation, Office of Highway Policy Information. (2015). "Urbanized Areas 2012: Miles and Daily Vehicle-Miles Traveled."

http:/www.fhwa.dot.gov/policyinformation/statistics/2012/hm71.cfm.

U.S. Energy Information Administration. (2013). "Electric power sales, revenue, and energy efficiency - Form EIA-861." Accessed December 15, 2014.

http://www.eia.gov/electricity/data/eia861/index.html. 


\section{Appendix A}

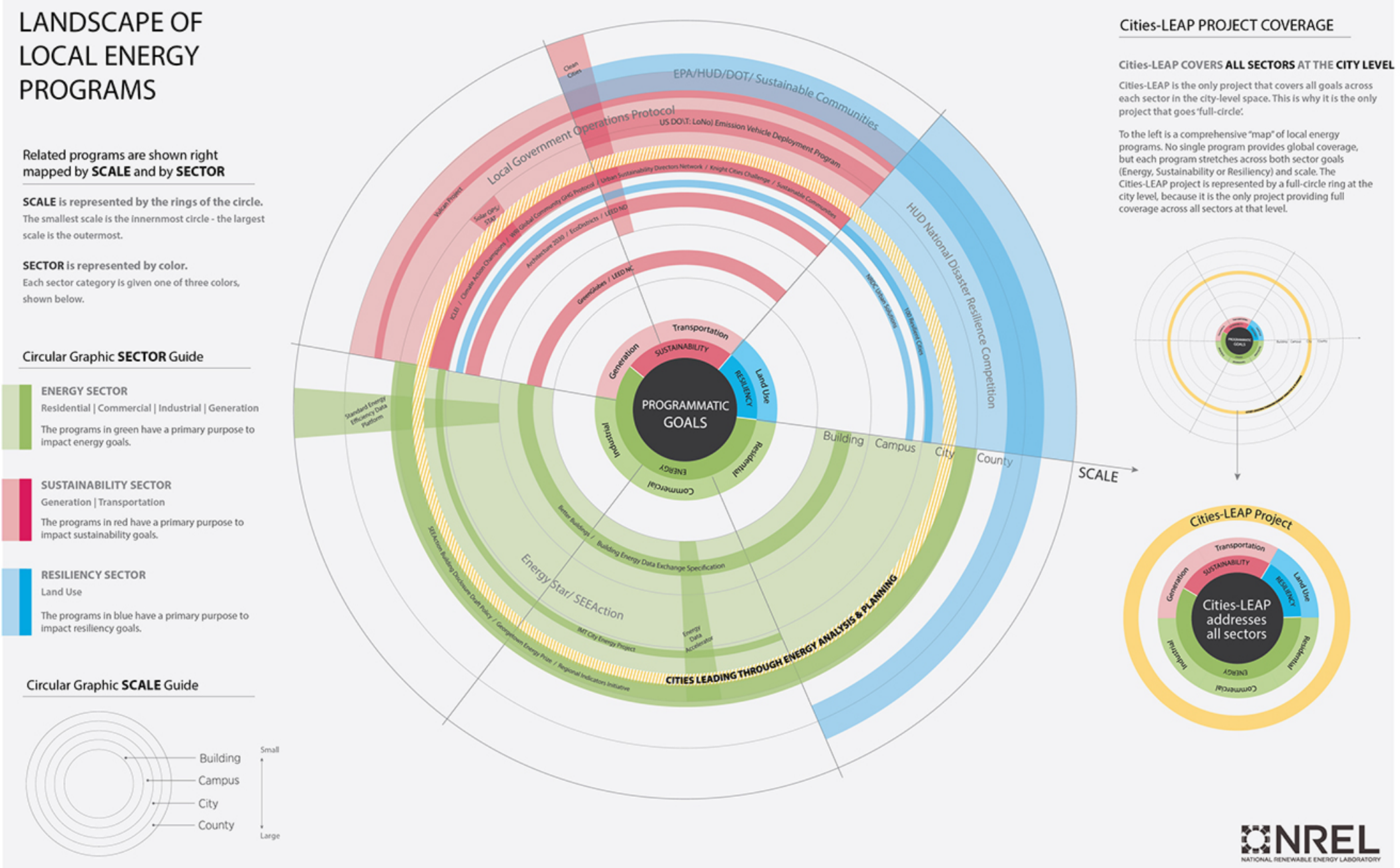




\section{Appendix B}

Table B-1: Classification of Actions

\begin{tabular}{|c|c|c|}
\hline Action Category & Action Subcategory & Standardized Action \\
\hline \multirow[t]{30}{*}{ Buildings \& Efficiency } & \multirow[t]{5}{*}{$\begin{array}{l}\text { Building Codes, Standards, \& } \\
\text { Certification }\end{array}$} & $\begin{array}{l}\text { Building certifications (LEED, etc.) and } \\
\text { best practices }\end{array}$ \\
\hline & & Building energy code updates \\
\hline & & $\begin{array}{l}\text { Specific building technologies (green } \\
\text { roofs, etc.) }\end{array}$ \\
\hline & & $\begin{array}{l}\text { Incentivize buildings to exceed building } \\
\text { codes }\end{array}$ \\
\hline & & Building code task force \\
\hline & \multirow[t]{6}{*}{$\begin{array}{l}\text { Building Upgrades \& } \\
\text { Improvements }\end{array}$} & $\begin{array}{l}\text { Retro-commissioning of existing buildings } \\
\text { (identification) }\end{array}$ \\
\hline & & $\begin{array}{l}\text { Appliance standards, upgrades, and } \\
\text { incentives }\end{array}$ \\
\hline & & Building lighting improvements \\
\hline & & HVAC upgrades \\
\hline & & Weatherization programs \\
\hline & & Occupancy schedule changes \\
\hline & \multirow[t]{4}{*}{ Heating \& Fuels } & Fuel switching for building heating \\
\hline & & Ban wood burning \\
\hline & & Expand natural gas distribution network \\
\hline & & Incentivize fireplace removal/change out \\
\hline & \multirow[t]{4}{*}{ Information \& Transparency } & Audit building energy usage \\
\hline & & Disclose building energy usage \\
\hline & & Benchmark building energy usage \\
\hline & & Make utility data accessible to consumers \\
\hline & Leading-by-Example & $\begin{array}{l}\text { Energy efficiency demonstration } \\
\text { programs }\end{array}$ \\
\hline & \multirow[t]{4}{*}{ Market Investment \& Financing } & Energy efficiency incentives \\
\hline & & Energy efficiency financing \\
\hline & & Energy efficiency loans \\
\hline & & Energy Service Companies (ESCO) \\
\hline & \multirow[t]{6}{*}{ Support \& Planning } & $\begin{array}{l}\text { Energy efficiency outreach \& awareness } \\
\text { campaigns }\end{array}$ \\
\hline & & Workforce training \& development \\
\hline & & $\begin{array}{l}\text { Actions recognizing \& addressing } \\
\text { building energy efficiency challenges }\end{array}$ \\
\hline & & Green leasing \\
\hline & & $\begin{array}{l}\text { Building point-of-sale energy efficiency } \\
\text { upgrades }\end{array}$ \\
\hline & & Goal setting-related to building energy \\
\hline
\end{tabular}




\begin{tabular}{|c|c|c|}
\hline Action Category & Action Subcategory & Standardized Action \\
\hline \multirow{10}{*}{$\begin{array}{l}\text { Electricity Use \& } \\
\text { Infrastructure }\end{array}$} & \multirow[t]{4}{*}{ Conservation \& Efficiency } & Energy conservation outreach \\
\hline & & $\begin{array}{l}\text { Direct engagement with large energy } \\
\text { consumers }\end{array}$ \\
\hline & & Energy efficiency ordinance \\
\hline & & $\begin{array}{l}\text { Goal setting for community energy } \\
\text { efficiency }\end{array}$ \\
\hline & \multirow[t]{6}{*}{ Infrastructure \& Generation } & Develop and deploy smart grids/meters \\
\hline & & Improve existing electricity infrastructure \\
\hline & & $\begin{array}{l}\text { Install, expand, and upgrade CHP/district } \\
\text { heating }\end{array}$ \\
\hline & & $\begin{array}{l}\text { Reduce emissions at existing generation } \\
\text { facilities }\end{array}$ \\
\hline & & Electricity co-ops \\
\hline & & $\begin{array}{l}\text { Retire fossil fuel based existing } \\
\text { generation facilities }\end{array}$ \\
\hline \multirow{23}{*}{$\begin{array}{l}\text { Municipal Operations \& } \\
\text { Programs }\end{array}$} & \multirow[t]{2}{*}{ Built Environment } & Install LED streetlights/traffic signals \\
\hline & & Reduction of urban heat island effects \\
\hline & \multirow[t]{3}{*}{$\begin{array}{l}\text { Community Outreach \& } \\
\text { Education }\end{array}$} & $\begin{array}{l}\text { Aspirational meetings/research/peer } \\
\text { learning in sustainability }\end{array}$ \\
\hline & & Solve existing community challenges \\
\hline & & Strengthen outreach with success stories \\
\hline & Emissions Goal Setting & Goal setting - Quantitative emissions \\
\hline & \multirow[t]{2}{*}{ Information \& Transparency } & Track and review municipal energy usage \\
\hline & & Update and publish GHG inventories \\
\hline & $\begin{array}{l}\text { Municipal Operations Goal- } \\
\text { Setting }\end{array}$ & $\begin{array}{l}\text { Goal setting - Municipal electricity } \\
\text { consumption }\end{array}$ \\
\hline & \multirow[t]{14}{*}{ Municipal Utilities } & Improve wastewater efficiency \\
\hline & & Miscellaneous municipal energy policies \\
\hline & & $\begin{array}{l}\text { Adopt sustainable procurement } \\
\text { standards for municipal purchases }\end{array}$ \\
\hline & & $\begin{array}{l}\text { Employee behavior energy use } \\
\text { assessment and education }\end{array}$ \\
\hline & & Hire sustainability/energy staff \\
\hline & & $\begin{array}{l}\text { Municipal computer energy management } \\
\text { policies }\end{array}$ \\
\hline & & $\begin{array}{l}\text { Incorporate emission impacts into } \\
\text { planning efforts }\end{array}$ \\
\hline & & $\begin{array}{l}\text { Set energy efficiency procurement } \\
\text { standard }\end{array}$ \\
\hline & & $\begin{array}{l}\text { Incorporate energy impacts into planning } \\
\text { efforts }\end{array}$ \\
\hline & & Occupy underutilized space \\
\hline & & $\begin{array}{l}\text { Peer learning and research in } \\
\text { sustainability }\end{array}$ \\
\hline & & Adopt sustainability engineering standard \\
\hline & & Four-day workweek options \\
\hline & & $\begin{array}{l}\text { Hire transportation demand management } \\
\text { coordinator }\end{array}$ \\
\hline
\end{tabular}




\begin{tabular}{|c|c|c|}
\hline Action Category & Action Subcategory & Standardized Action \\
\hline \multirow[t]{20}{*}{ Renewable Power } & \multirow[t]{2}{*}{ Codes \& Permitting } & $\begin{array}{l}\text { Streamline \& standardize distributed } \\
\text { generation permitting }\end{array}$ \\
\hline & & Zoning exceptions for renewable power \\
\hline & \multirow[t]{4}{*}{ Incentives \& Financing } & Other financing mechanisms \\
\hline & & $\begin{array}{l}\text { PACE (or equivalent) financing of } \\
\text { distributed generation }\end{array}$ \\
\hline & & $\begin{array}{l}\text { Promote existing state, utility, \& federal } \\
\text { incentives }\end{array}$ \\
\hline & & Municipal aggregation \\
\hline & \multirow[t]{9}{*}{ Local Power Generation } & $\begin{array}{l}\text { Distributed generation outreach \& } \\
\text { communication }\end{array}$ \\
\hline & & Solar photovoltaic development \\
\hline & & $\begin{array}{l}\text { Procure renewable power via PPAs or } \\
\text { RECs }\end{array}$ \\
\hline & & $\begin{array}{l}\text { Renewable power on municipal buildings } \\
\text { and facilities }\end{array}$ \\
\hline & & $\begin{array}{l}\text { Other renewable energy technologies } \\
\text { (Tidal, MSW, etc.) }\end{array}$ \\
\hline & & Waste to energy facilities \\
\hline & & $\begin{array}{l}\text { Encourage development of solar thermal } \\
\text { facilities }\end{array}$ \\
\hline & & Encourage development of wind facilities \\
\hline & & $\begin{array}{l}\text { Encourage development of geothermal } \\
\text { facilities }\end{array}$ \\
\hline & Other & Energy-related others \\
\hline & \multirow[t]{4}{*}{ Supporting } & Goal setting- Renewable energy \\
\hline & & $\begin{array}{l}\text { Coordinating state \& utility renewable } \\
\text { energy supply }\end{array}$ \\
\hline & & Sustainable energy policy \\
\hline & & Workforce development \& training \\
\hline \multirow{15}{*}{$\begin{array}{l}\text { Transportation \& Land } \\
\text { Use }\end{array}$} & \multirow{6}{*}{$\begin{array}{l}\text { Alternative Transit Incentives \& } \\
\text { Pricing }\end{array}$} & Public transit incentives \\
\hline & & VMT reduction incentives \\
\hline & & Bicycling incentives \\
\hline & & Alternative fuels adoption incentives \\
\hline & & Alternative vehicle adoption incentives \\
\hline & & $\begin{array}{l}\text { Employer based alternative transit/fuels } \\
\text { programs }\end{array}$ \\
\hline & \multirow[t]{8}{*}{ Codes, Laws, \& Enforcement } & Parking requirements \\
\hline & & Anti-idling \\
\hline & & Transit and congestion management \\
\hline & & Cooking and wood-fire emissions \\
\hline & & Vehicle emission standards \\
\hline & & $\begin{array}{l}\text { Implement low-carbon/renewable fuel } \\
\text { standard }\end{array}$ \\
\hline & & Small motor emissions \\
\hline & & Speed limit reduction and enforcement \\
\hline & Freight \& Airports & $\begin{array}{l}\text { Airport operational changes/infrastructure } \\
\text { investment }\end{array}$ \\
\hline
\end{tabular}




\begin{tabular}{|c|c|c|}
\hline Action Category & Action Subcategory & Standardized Action \\
\hline & & $\begin{array}{l}\text { Freight operational } \\
\text { changes/infrastructure investment }\end{array}$ \\
\hline & \multirow[t]{3}{*}{ Funding \& Programs } & Intelligent transportation systems \\
\hline & & Miscellaneous programs \\
\hline & & $\begin{array}{l}\text { Advocate to state and regional authorities } \\
\text { for sustainable transit funding }\end{array}$ \\
\hline & \multirow{13}{*}{$\begin{array}{l}\text { Improved Transportation Options } \\
\text { \& Infrastructure }\end{array}$} & Public transit service expansion \\
\hline & & Bicycle \& pedestrian infrastructure \\
\hline & & Ridesharing service \\
\hline & & Outreach programs \\
\hline & & Alternative fuel infrastructure \\
\hline & & Bike sharing service \\
\hline & & Install EV charging stations \\
\hline & & Live/work and work/live incentives \\
\hline & & Other public transit improvements \\
\hline & & Reach mode share targets \\
\hline & & Taxi fleet efficiency/emissions upgrades \\
\hline & & Certifications \\
\hline & & $\begin{array}{l}\text { Public transit vehicle efficiency } \\
\text { upgrade/replacement }\end{array}$ \\
\hline & \multirow[t]{8}{*}{ Municipal Fleet \& Freight } & Municipal operational changes \\
\hline & & Fleet fuel switching \\
\hline & & Fleet fuel efficiency standards \\
\hline & & Vehicle replacement \\
\hline & & Vehicle retrofits \\
\hline & & Fuel reduction goal \\
\hline & & Emissions reduction goal \\
\hline & & VMT goal \\
\hline & \multirow[t]{2}{*}{ Other } & Other-miscellaneous \\
\hline & & Improve efficiency of taxi vehicles \\
\hline & \multirow[t]{2}{*}{ Outreach \& Education } & $\begin{array}{l}\text { Locate city events around public transit } \\
\text { access }\end{array}$ \\
\hline & & Outreach on urban living benefits \\
\hline & \multirow[t]{7}{*}{ Planning } & $\begin{array}{l}\text { Walkable, complete, mixed-use } \\
\text { community planning }\end{array}$ \\
\hline & & $\begin{array}{l}\text { Regional transport planning, funding, \& } \\
\text { coordination }\end{array}$ \\
\hline & & Transit-oriented community planning \\
\hline & & Infill development planning \\
\hline & & Bicycle master planning \\
\hline & & Parking master planning \\
\hline & & Pedestrian master plan \\
\hline
\end{tabular}


Table B-2: Classification of Goals

\begin{tabular}{|c|c|c|}
\hline Goal Category & Goal Subcategory & Standardized Goal \\
\hline \multirow[t]{5}{*}{ Buildings } & \multirow[t]{5}{*}{ Building Energy Use } & $\begin{array}{l}\text { Reduce energy consumption } \\
\quad \circ \quad \text { for existing buildings through energy efficiency and } \\
\text { conservation measures }\end{array}$ \\
\hline & & $\begin{array}{l}\text { Increase number of buildings following green building } \\
\text { standards and codes }\end{array}$ \\
\hline & & $\begin{array}{l}\text { Reduce energy consumption } \\
\quad \quad \text { for newly constructed buildings }\end{array}$ \\
\hline & & $\begin{array}{l}\text { Increase neighborhood-level energy efficiency solutions } \\
\text { (energy districts, etc.) }\end{array}$ \\
\hline & & $\begin{array}{l}\text { Reduce energy consumption through retrofit, reuse and } \\
\text { repurpose } \\
0 \text { for buildings which have already been constructed }\end{array}$ \\
\hline \multirow[t]{3}{*}{ Efficiency } & Codes \& Standards & $\begin{array}{l}\text { Green the cities building codes } \\
\circ \text { through regular updating of codes } \\
\circ \text { including energy efficiency improvement measures }\end{array}$ \\
\hline & \multirow[t]{2}{*}{ Energy Use } & $\begin{array}{l}\text { Aspirational goals (qualitative) } \\
\circ \quad \text { to make electrical systems energy efficient }\end{array}$ \\
\hline & & $\begin{array}{l}\text { Quantitative goals } \\
\quad \circ \quad \text { to make electrical systems energy efficient }\end{array}$ \\
\hline \multirow[t]{3}{*}{ Emissions } & \multirow[t]{3}{*}{ Emissions } & Reduce community-wide greenhouse gas emissions \\
\hline & & Improve local air quality \\
\hline & & Reach carbon neutrality \\
\hline \multirow[t]{2}{*}{ Energy } & \multirow[t]{2}{*}{ Energy consumption } & $\begin{array}{l}\text { Aspirational goals } \\
\circ \text { to reduce energy consumption community wide }\end{array}$ \\
\hline & & $\begin{array}{l}\text { Explore and implement advanced and new energy } \\
\text { technologies }\end{array}$ \\
\hline \multirow[t]{7}{*}{ Renewable Power } & \multirow[t]{4}{*}{ Electricity Supply } & $\begin{array}{l}\text { Aspirational goals (qualitative) } \\
\circ \quad \text { to increase renewable energy generation and } \\
\text { consumption }\end{array}$ \\
\hline & & Increase local renewable energy generation \\
\hline & & $\begin{array}{l}\text { Quantitative goals } \\
\circ \quad \text { to increase renewable energy generation and } \\
\text { consumption }\end{array}$ \\
\hline & & Increase local market for renewable energy \\
\hline & \multirow[t]{3}{*}{ Technology Specific } & $\begin{array}{l}\text { Increase other renewable energy technologies (smart grid, } \\
\text { tidal, geothermal, etc.) }\end{array}$ \\
\hline & & Increase wind energy generation \\
\hline & & Increase solar energy generation \\
\hline \multirow[t]{4}{*}{ Sustainability } & $\begin{array}{l}\text { Education and } \\
\text { outreach }\end{array}$ & $\begin{array}{l}\text { Expand public energy education and raise awareness } \\
\text { about energy efficiency and conservation measures }\end{array}$ \\
\hline & \multirow{3}{*}{$\begin{array}{l}\text { Community and } \\
\text { business } \\
\text { sustainability }\end{array}$} & $\begin{array}{l}\text { Aspirational goals } \\
\circ \quad \text { to increase community-wide sustainability }\end{array}$ \\
\hline & & Encourage businesses to support sustainable activities \\
\hline & & Make project management processes more sustainable \\
\hline
\end{tabular}




\begin{tabular}{|c|c|c|}
\hline Goal Category & Goal Subcategory & Standardized Goal \\
\hline \multirow[t]{20}{*}{$\begin{array}{l}\text { Transportation \& } \\
\text { Land Use }\end{array}$} & & $\begin{array}{l}\text { Aspirational goals to } \\
\circ \quad \text { make city transportation more sustainable }\end{array}$ \\
\hline & Fuels & Reduce fossil fuel consumption in transportation \\
\hline & \multirow[t]{3}{*}{ Land Use } & $\begin{array}{l}\text { Increase mixed-use and transit oriented development in } \\
\text { cities }\end{array}$ \\
\hline & & $\begin{array}{l}\text { Create certified streets } \\
\quad \quad \text { E.g. Complete, Green, etc. }\end{array}$ \\
\hline & & Increase high-density and infill development \\
\hline & \multirow[t]{8}{*}{ Mobility } & $\begin{array}{l}\text { Increase walking and biking by improving related } \\
\text { infrastructure }\end{array}$ \\
\hline & & $\begin{array}{c}\text { Increase alternative commuting } \\
\circ \quad \text { Rail, water, clean vehicles etc. }\end{array}$ \\
\hline & & $\begin{array}{c}\text { Improve public transit } \\
\circ \quad \text { primarily buses }\end{array}$ \\
\hline & & Improve transit time and decrease congestion \\
\hline & & Increase public transit ridership \\
\hline & & Improve efficiency of freight operations \\
\hline & & Improve sustainability of airports \\
\hline & & Improve funding for sustainable transport \\
\hline & \multirow[t]{7}{*}{ Vehicles } & $\begin{array}{l}\text { Reduce transportation related emissions } \\
\circ \text { of city fleets, personal vehicles, air travel, water } \\
\text { travel etc. }\end{array}$ \\
\hline & & $\begin{array}{c}\text { Increase clean vehicle adoption } \\
\circ \quad \text { hybrid, EV, biofuel, etc. }\end{array}$ \\
\hline & & Increase the fuel efficiency of vehicles \\
\hline & & $\begin{array}{l}\text { Reduce VMT } \\
\quad \text { particularly of single occupancy trips }\end{array}$ \\
\hline & & $\begin{array}{l}\text { Reduce VMT } \\
\begin{array}{c}\text { increase shared trips (through carpooling and car } \\
\text { sharing) }\end{array}\end{array}$ \\
\hline & & Improve parking options for vehicles \\
\hline & & Reduce idling of vehicles through anti-idling laws \\
\hline Others & Others & Energy-related others \\
\hline
\end{tabular}

TableB-3: Classification of Metrics

\begin{tabular}{|c|c|c|}
\hline Metric Category & $\begin{array}{l}\text { Metric } \\
\text { Subcategory }\end{array}$ & Standard Metric \\
\hline \multirow[t]{5}{*}{$\begin{array}{l}\text { Buildings and } \\
\text { Efficiency }\end{array}$} & \multirow[t]{5}{*}{$\begin{array}{l}\text { Energy } \\
\text { Consumption }\end{array}$} & $\begin{array}{l}\text { City energy usage } \\
\circ \quad \text { by fuel type (e.g. natural gas) used in buildings }\end{array}$ \\
\hline & & $\begin{array}{l}\text { City energy usage } \\
\circ \quad \text { by electricity used in buildings }\end{array}$ \\
\hline & & Energy efficiency audits \\
\hline & & $\begin{array}{l}\text { Energy efficiency retrofits } \\
0 \quad \text { through efficiency and lighting upgrades }\end{array}$ \\
\hline & & Energy efficiency financing/ loans \\
\hline
\end{tabular}




\begin{tabular}{|c|c|c|}
\hline Metric Category & \begin{tabular}{|l|} 
Metric \\
Subcategory \\
\end{tabular} & Standard Metric \\
\hline & & $\begin{array}{l}\text { Metrics to measure energy consumption and reduction } \\
\text { buildings in cities } \\
\circ \quad \text { without fuel type or electricity usage specifications }\end{array}$ \\
\hline & Green Buildings & $\begin{array}{l}\text { LEED/Green building } \\
\circ \quad \text { permits issued and } \\
\circ \quad \text { codes implemented }\end{array}$ \\
\hline Renewable Power & Electricity Supply & $\begin{array}{l}\text { Renewable energy (RE) produced in a city including } \\
\circ \text { RE installations/permits } \\
\circ \quad \text { capacity (MW) } \\
\circ \text { \%of RE in energy mix }\end{array}$ \\
\hline \multirow[t]{15}{*}{$\begin{array}{l}\text { Transportation and } \\
\text { Land Use }\end{array}$} & \multirow[t]{6}{*}{ Vehicles \& Fuels } & $\begin{array}{l}\text { Conventional fuel use } \\
\circ \text { by different transportation means including city } \\
\text { fleets }\end{array}$ \\
\hline & & Number of vehicles in existing city fleets \\
\hline & & $\begin{array}{l}\text { Number of alternative vehicles in existing city fleets and } \\
\text { other transportation means }\end{array}$ \\
\hline & & EV charging station infrastructure \\
\hline & & Mileage of air and automobile travel \\
\hline & & Idling time of vehicles \\
\hline & \multirow[t]{5}{*}{ Mobility } & Public transit ridership \\
\hline & & VMT and total miles travelled \\
\hline & & 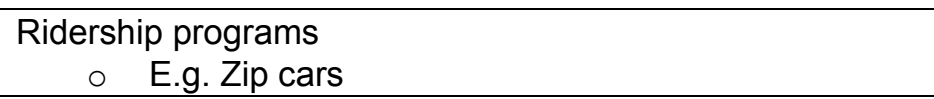 \\
\hline & & $\begin{array}{l}\text { Transit oriented development } \\
\circ \quad \text { E.g. \% of new housing units permitted within } 1,500 \\
\text { feet of rail, transit way, or rapid bus stop }\end{array}$ \\
\hline & & $\begin{array}{l}\text { Transport infrastructure } \\
\circ \quad \text { including transit stations, traffic signals and roads } \\
\text { built/ repaired }\end{array}$ \\
\hline & \multirow{4}{*}{$\begin{array}{l}\text { Bike \& Pedestrian } \\
\text { Infrastructure }\end{array}$} & Bike and pedestrian lane mileage \\
\hline & & Number of pedestrians/ bicycle commuters or both \\
\hline & & Bike racks installed and improved parking facilities \\
\hline & & $\begin{array}{l}\text { Walkability rating } \\
\quad \quad \text { E.g. Walkscore }\end{array}$ \\
\hline \multirow[t]{2}{*}{ Emissions } & \multirow[t]{2}{*}{ Emissions } & Greenhouse gas emissions measured community wide \\
\hline & & Criteria air pollutants by type and source \\
\hline \multirow[t]{2}{*}{$\begin{array}{l}\text { Economic } \\
\text { Development }\end{array}$} & \multirow[t]{2}{*}{$\begin{array}{l}\text { Sustainable } \\
\text { Development }\end{array}$} & $\begin{array}{c}\text { Certified sustainable businesses } \\
\circ \quad \text { Various certifications }\end{array}$ \\
\hline & & Green/clean energy jobs \\
\hline \multirow[t]{4}{*}{ Energy } & \multirow{4}{*}{$\begin{array}{l}\text { Energy } \\
\text { Consumption }\end{array}$} & Energy consumed community wide \\
\hline & & Energy efficiency financing/ loans \\
\hline & & Measuring existing costs and cost savings \\
\hline & & Energy Star certifications and appliances purchased \\
\hline \multirow[t]{3}{*}{ Others } & Energy related & Energy-related other metrics \\
\hline & $\begin{array}{l}\text { Education and } \\
\text { Outreach }\end{array}$ & Community outreach \& awareness- related other metrics \\
\hline & Water Efficiency & Water efficiency-related metrics \\
\hline
\end{tabular}

